SELTC TE D LOG S AND DRILLING

RECORDS OF WELLS AND TEST

HOLES D RILLED A T THE NEVA DAA

TEST SITE PRIOR TO 1960

By John E. Moore

UNITIED STATES DEPARTMENT OF THE THTHRIOR GEOLOGTCAL SURVEY

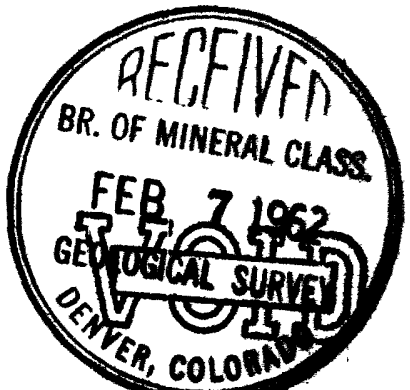


UNITED STATES DEPARTMENT OF THE INTERIOR

GEOLOGICAL SURVEY

\section{SELECTED LOGS AND DRILLING RECORDS OF WELLS AND TTEST HOLES DRILLED AT THE NEVADA TEST STTE PRIOR TO 1960*}

\section{By}

John E. Moore

January 1 62

Trace Elements Investigations Report

This report is preliminary and has not been edited for conformity with Geological Survey format.

*Prepared on behalf of the U.S.'Atomic Energy Commission.

Bureau of Land Management Library 


\author{
UNITED STATES \\ DEPARTMENT OF THE INTERIOR \\ GEOLOGICAL SURVEY \\ Washington, 25, D. C. \\ January 8, 1962
}

Mr. James E. Reeves

Assistant Manager for Test Operations

Albuquerque Operations Office

U. .S. Atomic Energy Commissión

P. 0. Box 5400

Albuquerque, New Mexico

Dear Mr. Reeves:

Transmitted, herewith, are ten copies of TEI-804, "Selected Iogs and drilling records of wells and test holes drilled at the Nevada Test S1te prior to 1960" by John E. Moore, January 1962.

We plan to release this report to the public in the open files.

Sincerely yours,

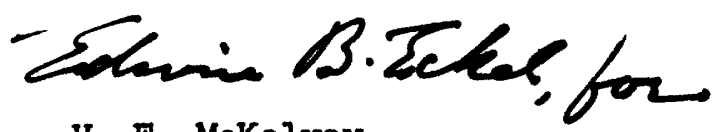

v. E. McKelvey

Assistant Chief Geologist Interagency Programs and

Supporting Activities 
Albuquerque Operations Office . . . . . . . . . . . . . . . 10

Division of Military Application, Washington . . . . . . . . . . 2

Division of Raw Materials, Washington . . . . . . . . . . . . . 2

Division of Research, Washington . . . . . . . . . . . . . . 1

Grand Junction Operations Office . . . . . . . . . . . . . . . 1

Las Vegas Area Office . . . . . . . . . . . . . . . . . . . . . 2

Office of Technical Information Extension .. . . . . . . . . . . . 2

Chemistry Division, Argonne National Lab. . . . . . . . . . . . . 1

Chemical Tech. Div., Oak Ridge Natl. Lab. . . . . . . . . . . . 1

Engineer Research \& Development Lab., Ft. Belvoir, Va.

(Chief, Speclal Projects Branch)................. 1

Health Physics Div., Oak Ridge Natl. Lab. . . . . . . . . . . . . . . 4

Lawrence Radiation Lab., Livermore. . . . . . . . . . . . . . . 25

Lawrence Radiation Lab., Mercury. . . . . . . . . . . . . . . . 3

Los Alamos Scientific Laboratory . . . . . . . . . . . . . . . 1

Los Alamos Scientific Laboratory . . . . . . . . . . . . . . 1

Sandia Corporation, Albuquerque . . . . . . . . . . . . . . . . 1

Stanford Research Institute, Menlo Park . . . . . . . . . . . . . . . 1

U.S. Naval Radiological Defense Lab., San Francisco . . . . . . . . . 1

Sandia Corporation, Mercury . . . . . . . . . . . . . . 2 
Radiohydrology Section, Washington . . . . . . . . . . . . 14

Geological Survey, Mercury, Nevada . . . . . . . . . . . . 10

Data Center, Mercury, Nevada . . . . . . . . . . . . . 20

Conservation Division ...................... 1

Englneering Geology . . . . . . . . . . . . . . . . . . . . 1

Geochemical Exploration and Minor Elements . . . . . . . . . 1

Organic Fuels......................... 2

New England ............................ 1

Eastern States........................ . 2

Central States........................ 1

Southern Rocky Mountains .. . . . . . . . . . . . . . . 2

Southwestern Branch ...... . . . . . . . . . . . . . . 1

Pactfic Coast States ...................... 1

Alaskan ............ . . . . . . . . . . . . . 1

Reglonal Geophysics . . . . . . . . . . . . . . . . 6

Paleontology and Stratigraphy . . . . . . . . . . . . . 5

Experimental Geochemistry and Mineralogy . . . . . . . . . . . 1

Theoretical Geophysics . . ................... . 4

Isotope Geology .. . . . . . . . . . . . . . . . . . . 1

Field Geochemistry and Petrology ................. 1

Analytical Laboratorles ...... . . . . . . . . . . . . . 1

Forelgn Geology ..... . . . . . . . . . . . . . . . . . . 1

Llbrary . . . . . . . . . . . . . . . . . . . . 3

Mil1tary Geology . . . . . . . . . . . . . . . . . 2

Special Projects . . . . . . . . . . . . . . . . . 12

Geologic Division . . . . . . . . . . . . . . . . 6 
CONTENTS

Page

Introduction ..................... 1

Murpose and scope ...................... 1

Location of area ................... 2

Source of information ................ 2

Previous reports . . . . . . . . . . . . . . 2

Topography ..................... 6

Geology .................... 6

Examination of samples ................ 9

Logs and drilling records ............... 9

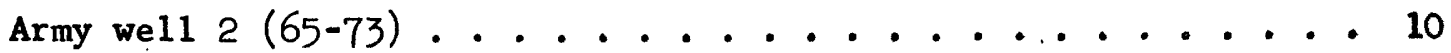

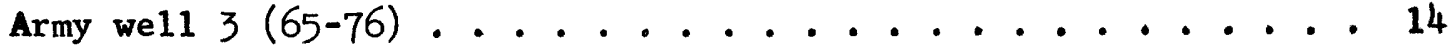

Army well 6A (66-69) . . . . . . . . . . . 17

Bureau of Land Management well $(66-72) \ldots . . . . . .20$

Army well $1(67-68) \ldots . . . . . . . . . . .21$

Army well $6(68-69)$. . . . . . . . . . . . . 26

Wel1 J-12 (73-58) . . . . . . . . . . . 27

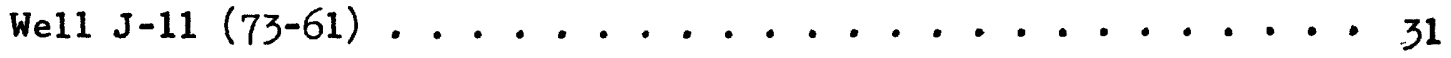

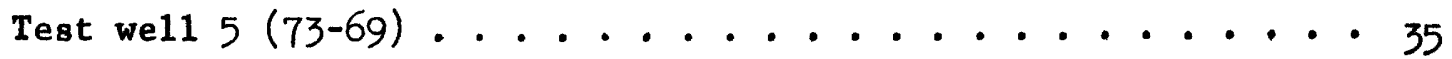

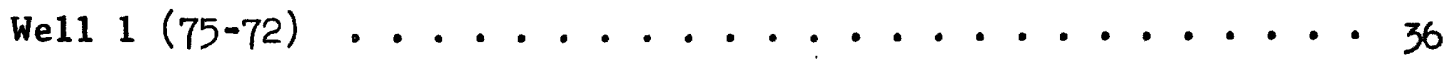

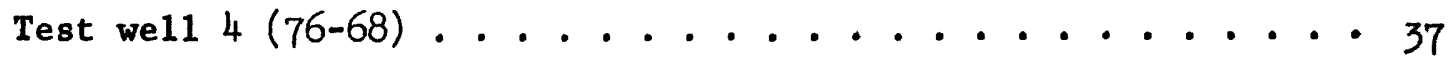

Gravity high test hole $2(83-67) \ldots . . . . . . . .38$

Grav1ty high test hole $1 .(87-66) \ldots \ldots 40$

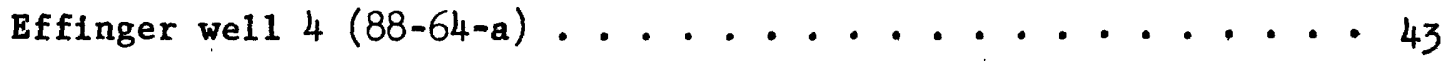

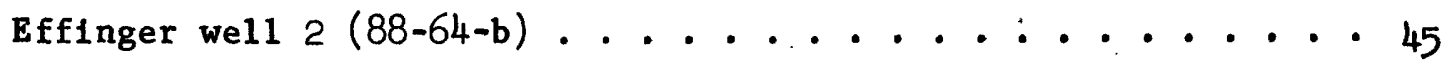


CONTENTS

Page

Logs and drilling records--Continued

Efflnger wel1 $1(88-65)$.............. 47

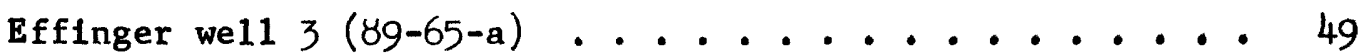

Watertown we11 $2(90-75)$............. 50

References cited . . . . . . . . . . . . . . 53

\section{ILLUSTRATIONS}

Figure 1. Map of Nevada Test Site and vicinity showing locations of wells and test holes described in this report.. 3

2. Electrica1 1 og of well J-12 .......... 30

3. Electrical log of well J-11 ........... 34

4. Electrical log of Watertown wel1 2........ 52

\section{TABLES}

Table 1. Lithologic logs available in other publications . . . 4

2. Avallability of chemical and radiochemical analyses of water and gamma-ray logs of wells described in this report .................... 5

3. Classification of rock formations in the Nevada Test Stte .................... 7

4. Depth to tuff and Paleozolc rock in test holes and we11s . . . . . . . . . . . . . . . . 


\section{SELECTED LOGS AND DRILLING RECORDS OF WELLS AND TEST HOLES DRILLED AT THE NEVADA TEST SITE PRIOR TO 1960}

By

John E. Moore

INTRODUCTION

Many we11s have been drilled for water at the Nevada Test Site since the Atomic Energy Commlssion began using the area for testing purposes. These wells afford information on the character and thickness of rocks to hundreds of feet below the land surface in a locallty where such information previously was almost entirely lacking. The logs of some of these wells have been reproduced in reports issued by the U. S. Geological Survey, but the logs of others, although equally useful in planning future drilling operations in the vicinity, have been scattered in different files. The present report brings together a11 the logs of we11s and test holes not published in previous reports.

\section{PURPOSE AND SCOPE}

This report 18 a compllation of 11 thologic $10 \mathrm{gs}$, drillers $10 \mathrm{gs}$, drflling records, and hydrologic data on 18 wells and test holes drilled In the Nevada Test Site and the surrounding area prior to 1960. A11 these holes except Gravity high 1 and 2 were drilled for hydrologic Information. Selsmic shot holes and core holes drilled in the tunnels in Ralnier Mesa are excluded. The records were collected as part of the hydrologic and geologic studies being made at the Nevada Test Site by the U. S. Geological Survey on behalf of the Atomic Energy Commission. 
Little interpretation 18 presented in this report, which is intended principally to supplement interpretative reports to be publidhed later.

\section{LOCATION OF AREA}

The area considered In this report includes the Nevada Test Site; Camp Desert Rock, to the south; Indian Spring Valley, to the southeast; and Emfgrant Valley, to the northeast $(\mathrm{f} 1 \mathrm{~g}, \mathrm{l})$. It is in Nye, Clark, and Lincoln counties. The nearest large city is Las Vegas, which is about $70 \mathrm{miles}$ to the southeast.

\section{SOURCE OF INFORMATION}

The $\log s$ and other data in this report were recorded by different Individuals and were obtained from different sources. They therefore lack uniformity in style and content, but are believed to afford the best Information available. The drillers' $10 \mathrm{gs}$ and details of well history have been obtained from the files of Reynolds Electrical and Englneering Co., Inc., and from unpublished reports of the U. S. Geological Survey. Samples from some of the wells and test holes had been preserved, and these were examined microscopically. The logs based on these samples are the most complete and detafled of those reported here.

\section{PREVIOUS REPORTS}

References to the 11 thologic $\log 8$ of wells and test holes avallable In other publications are given in table 1. 


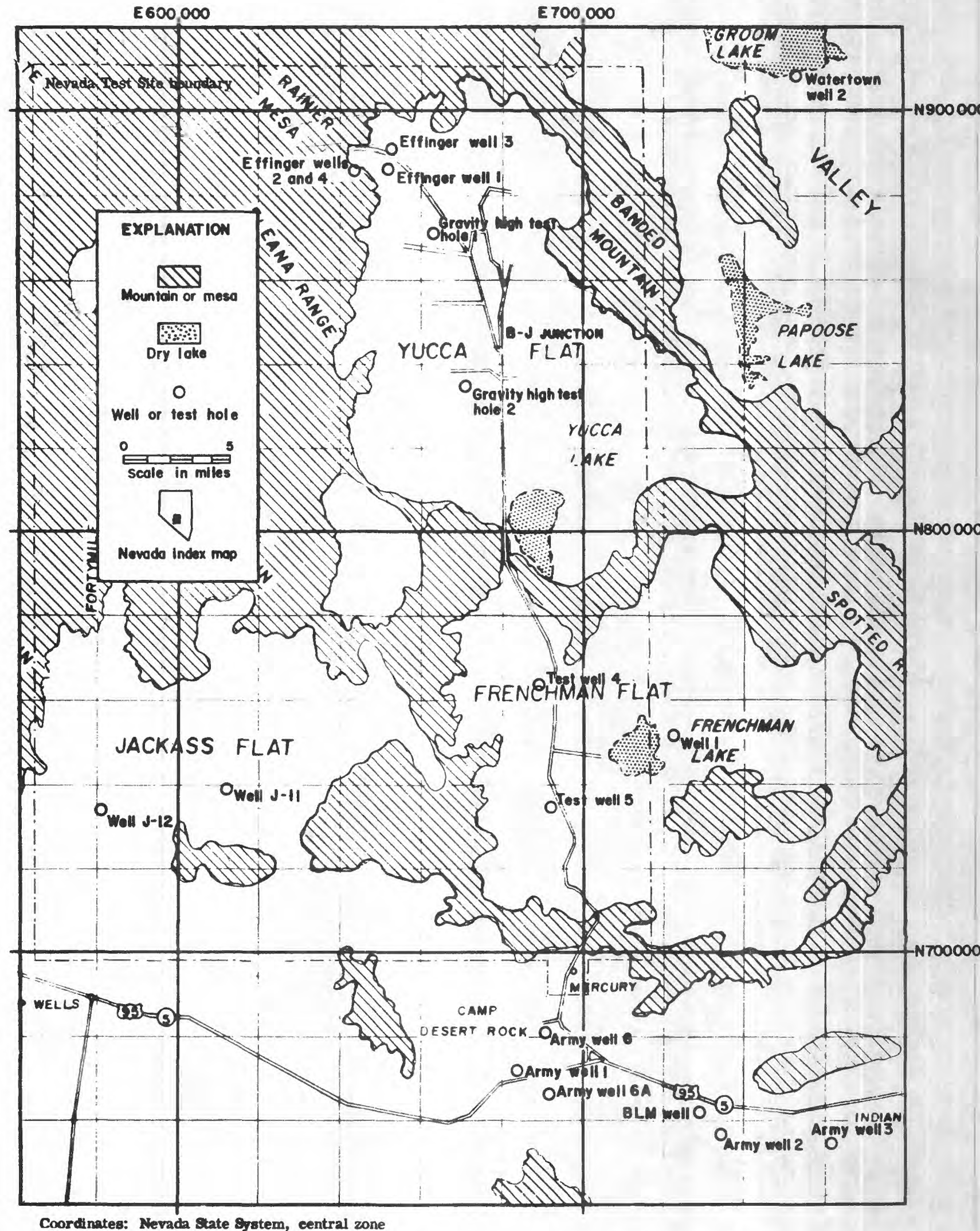

FIGURE 1. --MAP OF THE NEVADA TEST STTE AND VICINTTY SHOWING LOCATIONS OF WELLS AND TEST HOLES DESCRIBED IN THIS REPORT. 
Table 1.--Lithologic logs of wells and test holes at the Nevada Test Site reported in previous publications

\begin{tabular}{|c|c|c|}
\hline $\begin{array}{l}\text { We11 or test } \\
\text { hole no. }\end{array}$ & $\begin{array}{l}\text { Other no. } \\
\text { or name }\end{array}$ & Publication \\
\hline $73-70$ & We11 5A & $\begin{array}{l}\text { W1 lmarth, V. R., and other8, 1959, } \\
\text { TEI-358; Hood, J. W., 1961, } \\
\text { TEI-788. }\end{array}$ \\
\hline $74-70-a$ & Wel1 5B & $\begin{array}{l}\text { W1 1marth, V. R., and others, } 1959, \\
\text { TEI-358; Hood, J. W., 1961, } \\
\text { TEI-788. }\end{array}$ \\
\hline $74-70-b$ & We11 5C & $\begin{array}{l}\text { W1 1marth, V. R., and others, } 1959, \\
\text { TEI-358; Hood, J. W., 1961, } \\
\text { TEI-788. }\end{array}$ \\
\hline $81-67$ & We11 3 & $\begin{array}{l}\text { W1 1marth, V. R., and others, } 1959, \\
\text { TEI-358; Hood, J. W., 1961, } \\
\text { TEI-788. }\end{array}$ \\
\hline $84-68$ & Test we11 7 & $\begin{array}{l}\text { Wilmarth, V. R., and others, } 1959, \\
\text { TEI-358. }\end{array}$ \\
\hline $88-63-a$ & $\begin{array}{l}\text { Dolomite H111 } \\
\text { hole }\end{array}$ & $\begin{array}{l}\text { Dickey, D. D., and McKeown, F. A., } \\
\text { 1959, TEI-755. }\end{array}$ \\
\hline $88-63-c$ & U12e M1 & $\begin{array}{l}\text { Schoff, S. L., and Winograd, I. J., } \\
\text { 1961, TEI-787. }\end{array}$ \\
\hline $90-67-a$ & $\begin{array}{l}\text { Marble } 4 \text { or } \\
\text { ME } 4\end{array}$ & $\begin{array}{l}\text { Mckeown, F. A., and Wilmarth, V. R., } \\
\text { 1959, TEM-1036. }\end{array}$ \\
\hline $90-67-b$ & $\begin{array}{l}\text { Marble } 3 \text { or } \\
\text { ME3 }\end{array}$ & $\begin{array}{l}\text { Houser, F. N., and Pool, F. G., } 1959, \\
\text { TEM-1031. }\end{array}$ \\
\hline $90-67-c$ & $\begin{array}{l}\text { Marble } 1 \text { or } \\
\quad \text { ME1 }\end{array}$ & $\begin{array}{l}\text { Schoff, S. L., and Winograd, I. J., } \\
\text { 1961, TEI-787. }\end{array}$ \\
\hline $90-67-d$ & $\begin{array}{l}\text { Marble } 2 \text { or } \\
\text { ME2 }\end{array}$ & $\begin{array}{l}\text { Schoff, S. L., and Winograd, I. J., } \\
\text { 1961, TEI-787. }\end{array}$ \\
\hline $90-67-e$ & Granite hole & $\begin{array}{l}\text { Houser, F. N., and Poole, F. G., } \\
\text { 1959, TEM-836. }\end{array}$ \\
\hline
\end{tabular}


Chemical and radiochemical analyses of the water from test holes and we11s considered here are given in a report by Moore (1961). Gamma-ray logs for 5 of these wells are shown in a report by Bunker (1961). Table 2 shows the avallability of chemical and radiochemical analyses of water and gamma-ray logs of wells described in this report.

Tab1e 2.--Avallability of chemical and radiochemical analyses of water and gamma-ray logs of wells described in this report.

\begin{tabular}{|c|c|c|c|}
\hline $\begin{array}{l}\text { We11 or test } \\
\text { hole no. }\end{array}$ & $\begin{array}{l}\text { Other no. } \\
\text { or name }\end{array}$ & $\begin{array}{l}\text { Chemical and } \\
\text { radiochemical } \\
\text { analyses (Moore, } \\
1961 \text { ) }\end{array}$ & $\begin{array}{l}\text { Gamima-ray 10g8 } \\
\text { (Bunker, 1961) }\end{array}$ \\
\hline $65-73$ & Army we11 2 & $x$ & $\mathbf{x}$ \\
\hline $65-76$ & Army we11 3 & $\mathrm{x}$ & $\mathrm{x}$ \\
\hline $66-69$ & Army we11 $6 \mathrm{~A}$ & $\mathbf{x}$ & $\mathrm{x}$ \\
\hline $66-72$ & $\begin{array}{l}\text { Bureau of Land } \\
\text { Management }\end{array}$ & -- & $\cdots$ \\
\hline $67-68$ & Army we11 1 & --- & $\mathbf{x}$ \\
\hline $68-69$ & Army we11 6 & --- & $\cdots$ \\
\hline $73-58$ & We11 J-12 & $\mathrm{x}$ & $\mathrm{x}$ \\
\hline $73-61$ & We11 J-11 & $\mathrm{x}$ & $\cdots$ \\
\hline $73-69$ & Test well 5 & --- & -- \\
\hline $75-72$ & We11 1 & --- & -- \\
\hline $76-68$ & Test we11 4 & -- & $-\cdots$ \\
\hline $83-67$ & Gravity high 2 & --- & -- \\
\hline $87-66$ & Gravity high 1 & -- & $-\cdots$ \\
\hline $88-64-a$ & Eff1nger we11 4 & --- & $\mathrm{x}$ \\
\hline $88-64-b$ & Effinger we11 2 & $\cdots$ & $\mathrm{x}$ \\
\hline $88-65$ & Effinger we11 1 & --- & $\mathrm{x}$ \\
\hline $88-65-a$ & Effinger wel1 3 & --- & $\mathrm{x}$ \\
\hline $90-75$ & Watertown we11 2 & $\mathbf{x}$ & $\cdots$ \\
\hline
\end{tabular}




\section{TOPOGRAPHY}

The Nevada Test Site is in the Great Basin and 18 characterized by mountain ranges and intermontane valleys. The mountain ranges reach altitudes of 5,000 to 7,500 feet and the flat valley bottoms are at altitudes of 3,200 to 4,500 feet.

The report area Includes five major valleys: Yucca, Frenchman, Jackass, Indian Spring, and Finfgrant Valleys. The first three of these valleys are within the boundaries of the Nevada Test Site.

\section{GEOLOGY}

The rocks exposed in the Nevada Test Site consist of varied sedimentary rocks of $\mathrm{Paleozolc}$ age, volcanlc and sedimentary rocks of Tertlary age, and alluvial and playa deposits of Quaternary age (Johnson and H1bbard, p. 335-336, 1957; Hansen and Lemke, 1958). The Paleozolc rocks have a total thickness of about 22,000 feet and are dominantly 11mestone and dolomite, together with marble, quartzite, argil11te, shale, and conglomerate. The Paleozolc rocks have been Intruded at a few places by a granodiorite stock and by dikes of Cretaceous or Tertlary age. The overlying Tertiary rocks consist principally of vitric and zeolitic tuff, basa1t, rhyolite, and rhyodacite of the Oak Spring Formation of Mlocene(?) or younger age. The Tertiary and Quaternary alluvium consists principally of detritus deposited in the intermontane basins, much of it In the form of fans. The rocks are folded and are cut by thrust faults and normal faults (Johnson and Hibbard, p. 369, 1957). The bedrock of the Nevada Test Site includes the formations 11sted in table 3. 
Table 3.--Classification of rock formations in the Nevada Test Site (summarized from Barnes, Houser, and Pool, 1961)

Tertiary System

Miocene (?) or younger

Oak Spring Formation

Lower Pennsylvanian to Lower Permian (?)

Tippipah Limestone

Mississippian to Lower Pennsylvanian

Eleana Formation (argilite, shale, conglomerate, and quartzite)

Lower Mississippian

Mercury Limestone

Upper Devonian and Lower Mississippian

Narrow Canyon Limestone

Middle and Upper Devonian

Devils Gate(?) Limestone

Lower and Middle Devonian

Nevada Formation (dolomite, limestone, and quartzite)

Ordovician to Devonian

Dolomite, undifferentiated

Middle Ordovician

Eureka Quartzite

Lower and Middle Ordoviclan

Pogonip Group (11mestone and some dolomite and shale)

Cambrian System

Wind fall Formation

Dunderberg Shale

Bonanza King Formation

Cad1z Formation

Wood Canyon Formation 
The wells and test holes included in this report penetrate the following stratigraphic units: Oak Spring Formation, Eleana Formation, Pogonip Group, Windfall Formation and Bonanza King.Formation. The depths to tuff and Paleozoic rock, as Indicated by test holes and wells, are shown in table 4.

Table 4.--Depth to tuff and Paleozolc rock in test holes and wells, in feet below land surface

\begin{tabular}{|c|c|c|c|c|c|}
\hline $\begin{array}{c}\text { Well or } \\
\text { test } \\
\text { hole no. }\end{array}$ & $\begin{array}{c}\text { Other no. } \\
\text { or } \\
\text { name }\end{array}$ & $\begin{array}{l}\text { Depth of } \\
\text { well }\end{array}$ & $\begin{array}{l}\text { Depth to } \\
\text { tuff }\end{array}$ & $\begin{array}{l}\text { Depth to } \\
\text { Paleozolc } \\
\text { rock }\end{array}$ & $\begin{array}{c}\text { Lithology } \\
\text { of } \\
\text { Paleozolc } \\
\text { rock }\end{array}$ \\
\hline $65-76$ & Army wel1 3 & 830 & 380 & -- & --- \\
\hline $66-69$ & Army wel1 $6 \mathrm{~A}$ & 1,253 & -- & 30 & Quartzite \\
\hline $67-68$ & Army wel1 1 & 620 & 360 & 610 & Dolomite \\
\hline $73-58$ & We11 J-12 & 887 & 515 & $\cdots$ & $\cdots$ \\
\hline $73-61$ & We11 J-11 & 1,329 & 1,150 & $\cdots$ & $\cdots$ \\
\hline $87-66$ & Gravity high 1 & 145 & $\cdots$ & 130 & Dolomite \\
\hline $88-64-a$ & Effinger we11 4 & 76 & 65 & $\cdots$ & $\cdots$ \\
\hline $88-64-b$ & Effinger well 2 & 80 & $\cdots$ & 40 & Argillite \\
\hline $88-65$ & Effinger well 1 & 180 & $\cdots$ & 165 & Quartzite \\
\hline $88-65-a$ & Effinger well 3 & 202 & -- & 190 & Arg1111te \\
\hline
\end{tabular}




\section{EXAMINATION OF SAMPLES}

Survey geologists examined the cuttings or cores collected from the following holes: Army wells 1 through 3 and $6 \mathrm{~A}$; we11s $\mathrm{J}-11$ and -12 ; Gravity h1gh holes 1 and 2; Effinger wells 1 through 4 . Samples from the remalning holes were not avallable for study.

The avallable cuttings first were washed free of dril1ing mud and then they and the cores were examined under a binocular microscope for determination of mineralogy, texture, size, roundness, and color of individual constituents. Colors of the samples were compared with the standard colors of the National Research Counc1l rock color chart (Goddard and others, 1951).

The logs of Army wells 1,2, and 3 describe the grain sizes in the alluvium. It should be polnted out, however, that they are at best only estimates of the natural size ranges because the materials had been. altered by crushing and disaggregation by the drill bit.

\section{LOGS AND DRILLING RECORDS}

The records of the 19 wells and test holes included in this report are given on the pages that follow. A driller's log is given where a geologist's $\log$ is not available. The locations of all wells and test holes are shown in figure 1.

The location numbers that follow the name of the well or test hole are based on the Nevada State Coordinate System, central zone. Each number consists of three parts; the first two digits of the north coordinate, the first two digits of the east coordinate, and a letter to distinguish the individual well from others in the same 10,000 -foot 
square. The we11s and test holes are arranged according to these numbers, which are given in parentheses following the name of the well.

$$
\text { Army well } 2 \text { (65-73) }
$$

Army well 2, also known as Army 6C, was Intended for supply1ng water to Camp Desert Rock, an Army post. It is in the western part of Ind1an Spring Valley about 11 miles southeast of Mercury. The Nevada State Coordinates of the site are N 655,582 and E 735,166 and the landsurface altitude at the well 1 s 3,813 feet.

The well was drilled in 1958 by the Mckinney Dril11ng Co., using the cable-tool method. It 18658 feet deep and 1s cased from the surface to 92 feet with 10-1nch blank casing. The yield was reported by the driller as only 8 to 10 gallons per minute. The well was abandoned because the yield was too 11ttle to fulfill the water needs of the camp. The well penetrated only alluvium of Quatemary and/or Tert1ary age, consisting principally of fine- to medium-grained dolomite and quartzite fragments in a calcareous-silt matrix. These materials are relatively homogeneous except in the interval from 620 to 630 feet, where abundant fragments of crystal tuff are included.

The static water level in the well in May 1961 was 501.6 feet below the 1and surface. 
Geolog1st's $\log$ of Army well 2

Alluvium

Sand, grave1, and silt; very pale orange and dark gray; consisting of dolomfte (dark gray to 11ght gray, fine to medium grained, subangular to round) with minor amounts of basalt (black, angular), chert (white, subangular), quartzite (rose, subangular), arglilite (medium gray, subround to angular), and calclum-carbonate fragments (very pale orange); many dolomite and basalt grains covered with calcium carbonate (very pale orange); matrix, calcareous silt (very pale orange) ....................... 50

Simllar, but with addition of minor quantities of calcite crystals and sand-sized quartz crystals .............. 10

Sand and silt; very pale orange, pale purple and dark gray; composed of dolomite (dark gray to light gray, fine to medium gralned) and quartzite (rose to pale purple, subangular) with minor amounts of chert (white, subangular), argil11te (medium gray and 
Geologiat's log of Army we11 2--Continued

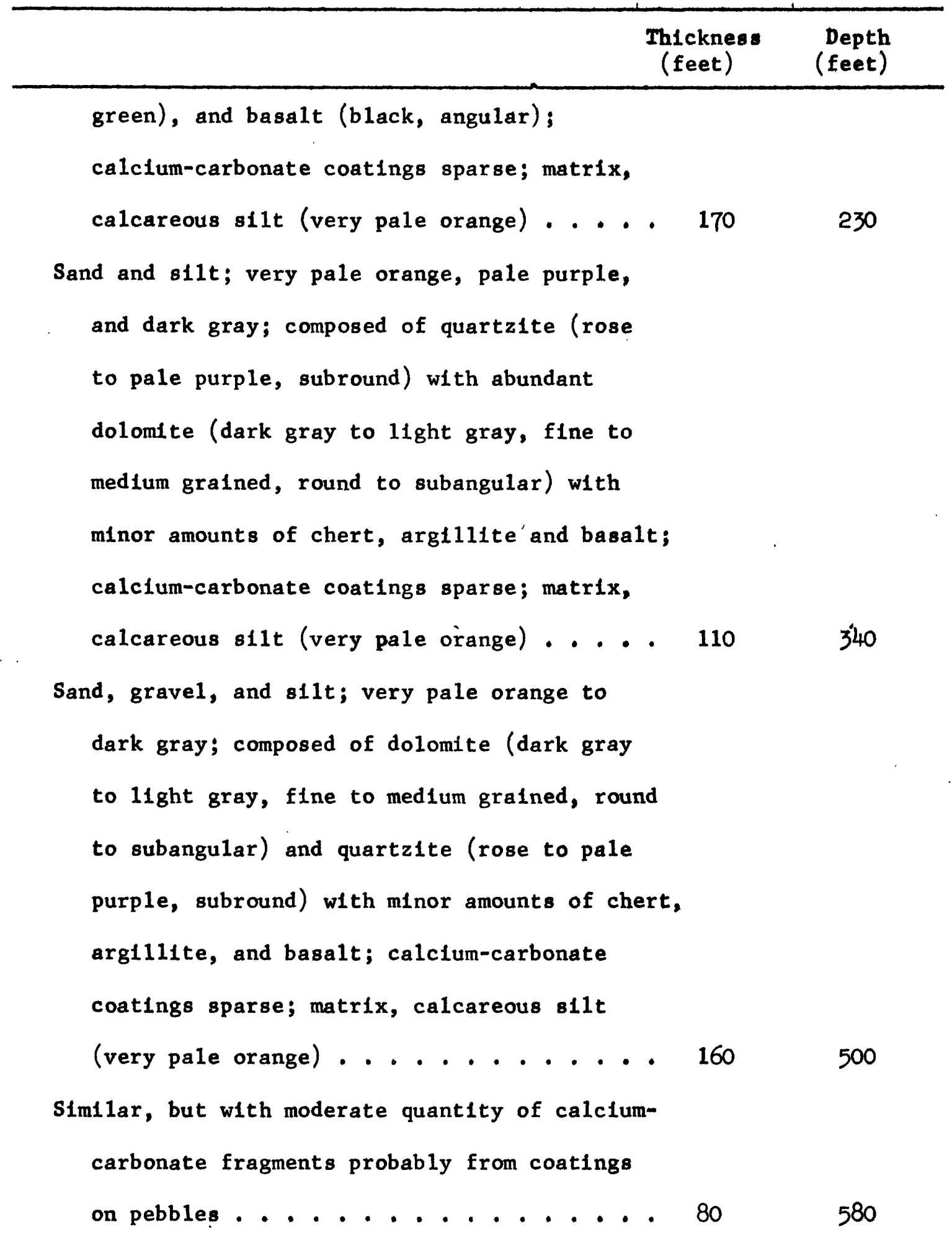


Geologist's $\log$ of Army well 2--Continued

Sand; very pale orange and dark gray; composed of dolomite (dark gray to 11ght gray, fine to medlum gralned, round to subangular) and quartzite (rose to pale purple, subround to subangular) with minor amounts of crystal tuff (pinkish gray, fine to medium grained, calcareous, containing phenocrysts of quartz, and feldspar), chert, and arg1llite; calciumcarbonate coatings sparse ....... 40

Sand and s11t; p1nk1sh gray and dark gray; composed primarily of crystal tuff (pinkish gray, calcareous, contalning abundant euhedral to subhedral phenocrysts of quartz and feldspar, and scattered grains of magnetite, blotite, and amphtbole), with moderate amounts of dolomite, quartzite, argillite, and chert .... 10

Gravel and sand; pink1sh gray and dark dusky red to dark gray; composed primarily of 11mestone (graylsh red to very dark dusky red, fine grained, angular to subangular) and dolomite (dark gray, fine to medium grained) with minor amounts of crystal tuff, quartzite, and chert; calclum-carbonate coatings sparse . . . . 28 
Army we11 $3(65-76)$

Army we11 3, also known as Army 6D, was intended for supply1ng water to Camp Desert Rock, an Army post. It is in the western part of Indian Spring Valley about $15 \mathrm{mlles}$ southeast of Mercury. The Nevada state Coordinates are N 654,163 and $\mathrm{E} 760,615$ and the land-surface altitude at the we11 is $3,616.9$ feet.

The well was drilled in 1958 by the McK1nney Drilling Co., using the cable-tool method. It 18830 feet deep and 1s uncased. The yleld as reported by the driller based on a 4-hour test was 113 gallons per minute.with a drawdown of 79 feet. It was reported that the water level was drawn down to the pump ( 300 feet) at the end of the pumping period.

The hole penetrated alluvium from the surface to 380 feet and tuff from 380 feet to the bottom at 830 feet. The alluvium is of quaternary and/or Tertlary age and consists primarily of fine- to medium-gralned dolomite and quartzite fragments in a matrix of calcareous silt. The tuff is thought to be correlative with the Oak Spring Formation of Tertlary age. It 18 friable and contains numerous quartz and feldspar phenocrysts.

The static water level in the well in January 1960 was 287.3 feet below the land surface. 


\begin{tabular}{ccc}
\hline & $\begin{array}{c}\text { Thickness } \\
\text { (feet) }\end{array}$ & $\begin{array}{c}\text { Depth } \\
\text { (feet) }\end{array}$ \\
\hline
\end{tabular}

Alluvium

Sand, gravel, and silt; very pale orange and dark gray; consisting of dolomite (dark gray, fine to medium grained, subangular to round) and quartzite (rose, subangular) with minor amounts of argillite (medium gray to green, subround to round), and chert (white, subangular); calclum-carbonate coatings common; matrix, calcareous silt (very pale orange). . 30

Similar, but with addition of a minor amount of basalt ............... 40

Sand, grave1, and s11t; very pale orange and

dark gray; consisting of quartzite (rose to pale purple, subangular to subround) with abundant dolomtte (dark gray, flne gralned, subangular to round) and minor amounts of chert, argillite, and basalt; calcium-carbonate coatings sparse; matrix, calcareous silt (very pale orange) .............. 120

Sand, silt, and grave1; very pale orange to dark gray; composed of quartzite (rose to pale purple, subangular to subround) with abundant dolomtte (dark gray, fine grained) and minor amounts of 
Geologist's log of Army well 3--Cont1nued.

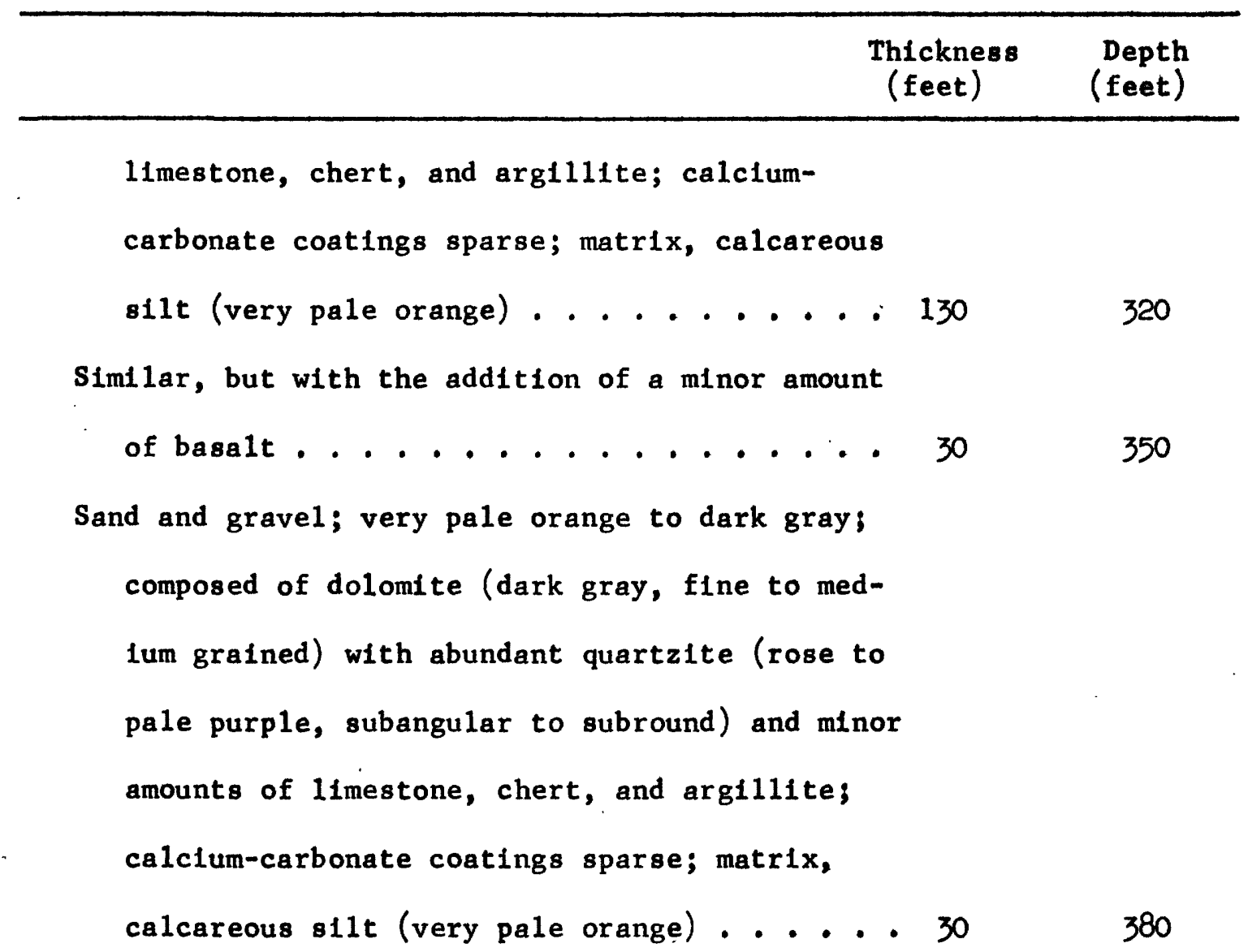

Bedrock

Tuff, crystal, friable; pinkfsh gray to 11ght brownlsh gray; composed of quartz and feldspar crystals (medium to fine sand, euhedral to subhedra1) with a moderate amount of magnetite and blotite; matrix, calcareous silt (very pale orange to pale yellowlsh brown) .... $450 \quad 830$ 
Army we11 6A (66-69)

Army well $6 \mathrm{~A}$, also known as the Rless well from the name of the Army's consultant for the job, was intended for supplying water for Camp Desert Rock, an Army Post. It is in the same valley as the camp, and is about $6 \mathrm{mlles}$ south of Mercury. The Nevada State Coordinates of the site are $\mathrm{N} 665,641$ and $\mathrm{E} 690,214$, and the 1and-surface altitude at the well is 3,445 feet.

The we11 was drilled to a depth of 1,253 feet in 1955 by the Allen Water Well Co. It is cased with 12-inch casing from the surface to 1,185 feet and with $10-1$ nch casing from 1,157 to 1,228 feet. The 10-inch casing is perforated in the interval from 1,157 to 1,228 feet. The yield of the well was only 1 to 2 gallons per minute. This was too little to fulfili the needs of the camp and the well was abandoned. The well penetrated 30 feet of alluvium underlain by quartzite, limestone, and siltstone.

The static water level in the well in January 1960 was 1,031 feet below the land surface. 
Geologist's $\log$ of Army well 6A

By James Huber

Thickness

Depth

(feet)

(feet)

Alluvium

Sand, gravel, and silt; pale orange; consisting

of quartz, quartzite, and fine-grained

Igneous rock; matrix, silt ....... 30

30

Bedrock

Quartzite; brownish gray and olive gray; consisting of quartzite with minor amounts of Iron oxide, mica, and feldspar ..... $510 \quad 540$

Limestone; 11ght graylsh red; conslsting of

medium-grained limestone, some coated with 1ron oxide................ 10 550

Quartzite; medium ollve gray and medium brownish

gray; containing fine- to medium-grained

quartzite with minor amounts of ferromagnesian

minerals and mica ........ 120

670

Sandstone; grayish red; fine-gralned sandstone,

metamorphosed, calcareous ....... 20

690

Quartzite; 1ight brownish gray; quartzite with

minor amounts of magnetite, mica, and Iron

oxide ............. 140

S11tstone; 11ght grayish red; fine-grained silt-

stone, metamorphosed, laminated bedding . . 70 
Geolog1st's log of Army wel1 6A--Continued.

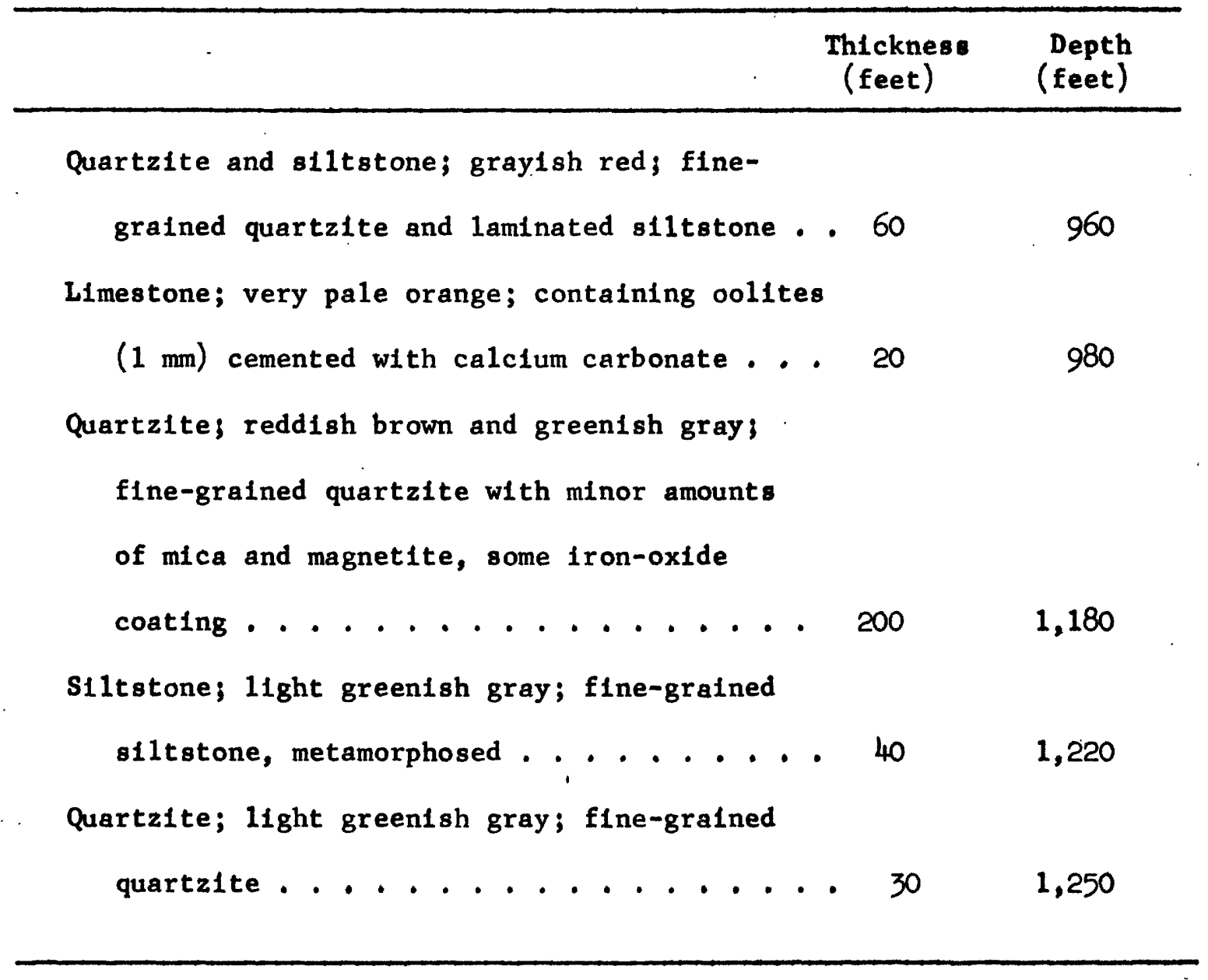


Bureau of Land Management wel1 (66-72)

The Bureau of Land Management well is in the western part of Indian Spring Valley about $8 \mathrm{mlles}$ southeast of Mercury. The Nevada State Coordinates of the site are $N 662,361$ and $E 728,800$, and the land-surface altitude at the we11 is 3,647 feet.

J. L. Hogen drilled the well by the cable-tool method In 1951. The well was abandoned as a dry hole at a depth of 587 feet because of a shortage of fund $s$.

Dr11ler's log of the Bureau of Land Management well

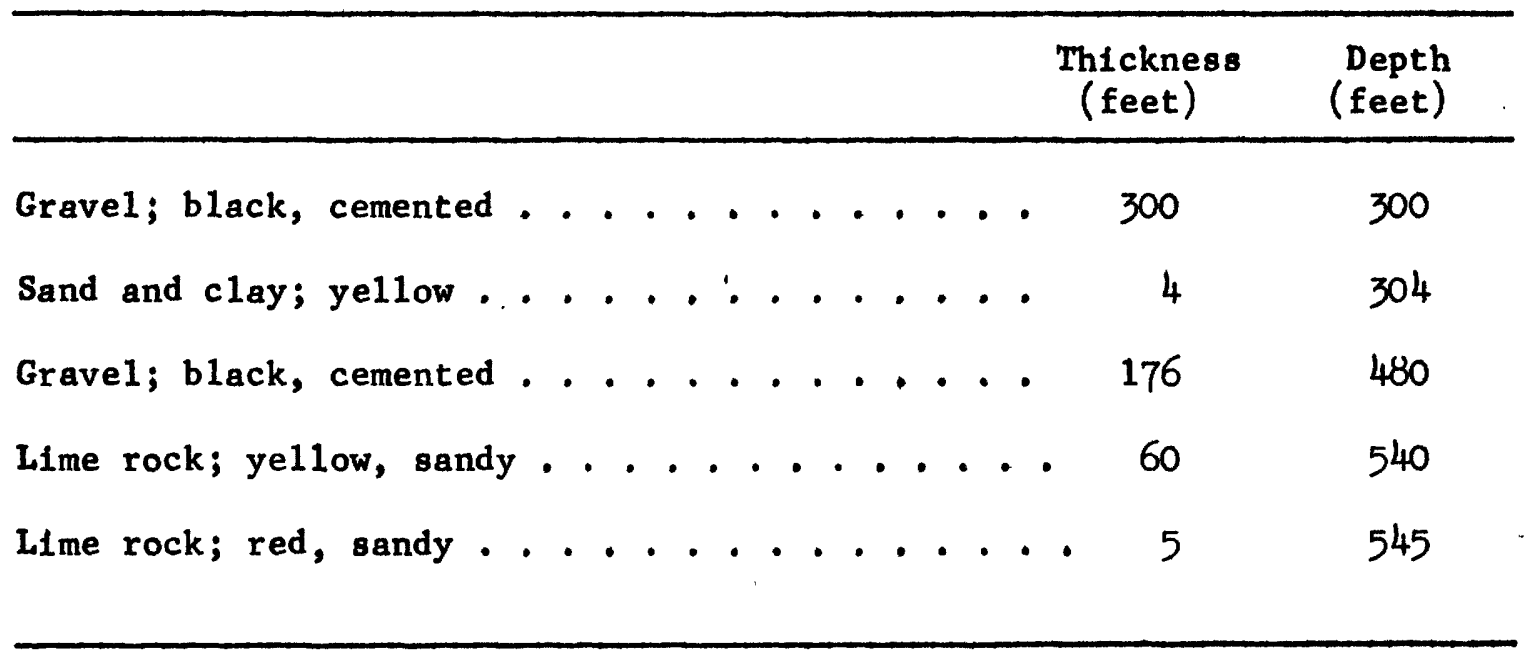


Army we11 $1(67-68)$

Army wel1 1 , also known as Army 6B, was intended for supplying water to Camp Desert Rock, an Army post. It is in the same valley as the camp and is about $6 \mathrm{miles}$ southwest of Mercury. The Nevada State Coordinates of the site are $N 670,800$ and $\mathrm{B} 683,700$, and the land-surface altitude at the well is about 3,110 feet.

The well was drilled in 1958 by the McKinney Drilling Co., using the cable-tool method. It is 620 feet deep and is uncased except for a few feet of surface pipe. Drilling was stopped when dolomite was penetrated because the Army's consultant believed that the dolomite contains no water.

The hole penetrated alluvium from the surface to 360 feet, tuff from 360 to 515 feet, alluvium from 515 to 610 feet, and dolomite from 610 feet to the bottom at 620 feet.

The alluvium is of Quaternary and/or Tertiary age and consists principally of fine- to medium-grained dolomite and quartzite fragments In a matrix of calcareous silt.

The bed of tuff is thought to be correlative with the Oak Spring Formation of Tertiary age. It is friable and is composed of fragments of pumice and crystals of quartz, feldspar, and biotite.

The dolomite is dark gray and is fine- to medium-grained. It is similar in mineralogy, texture, and color to outcrop samples of dolomite of Upper Cambrian age (WIndfall Formation) obtalned 1 mile west of the test hole. 
Geologist's $\log$ of Army well 1

Alluvium

Sand, silt, and gravel; plnklsh gray and pale purple; composed of quartzite (rose to purple, subangular to subround) and minor amounts of argillite (green to brown, round to subround), mica schlst (subround), and chert (white, subangular to round); matrix, calcareous silt (very pale orange) . . . . . . . . . . . 40

Simflar, but many of the quartzite grains

partially coated with calcium carbonate . . 30

Sand, s11t, and gravel; pinkish gray to yellowish

gray and pale purple; composed of quartzite

(rose to pale purple, angular to subround)

with minor amounts of arg1111te, chert,

basalt (black, subangular), and tuff (plnkish

gray, calcareous); many quartzite grains

partially covered with calcium-carbonate;

matrix, calcareous silt (very pale orange) . 35

Sand, silt, and grave1; pinkish gray to

yellowish gray; consisting of quartzite

(rose to pale purple, angular to subround)

and minor amounts of dolomite (dark gray, 
Geologist's $\log$ of Army well 1--Continued

\begin{tabular}{cc}
\hline $\begin{array}{c}\text { Th1ckness } \\
\text { (feet) }\end{array}$ & $\begin{array}{c}\text { Depth } \\
\text { (feet) }\end{array}$ \\
\hline
\end{tabular}

medium to fine grained, angular to subround), crystal tuff, calclum-carbonate fragments, mica schist, chlorite schist, and argillite; many quartzite and dolomite grains covered with calcium carbonate; matrix, calcareous silt (very pale orange).......... 35 140

Simflar, but with calclum carbonate partially coating most dolomite and quartzite gralns . . 55

Sand, s11t, and grave1; pinkish gray to dark gray; composed of quartz1te (rose to pale purple, angular to subround) and dolomt te (dark gray, medium to fine grained) with minor amounts of argil11te, tuff, and chert; calclum-carbonate coatings sparse; matrix, calcareous silt (very pale orange) . . . 70 Sand, grave1, and silt; 11ght gray to dark gray; unconsolidated; composed primarily of dolomite (1ight to dark gray, medium to fine grained) with abundant quartzite and minor amounts of chert, argilite and tuff; calclum-carbonate coatings sparse; matrix, calcareous silt (very pale orange) . 95 
Geologist's $\log$ of Army well 1--Continued.

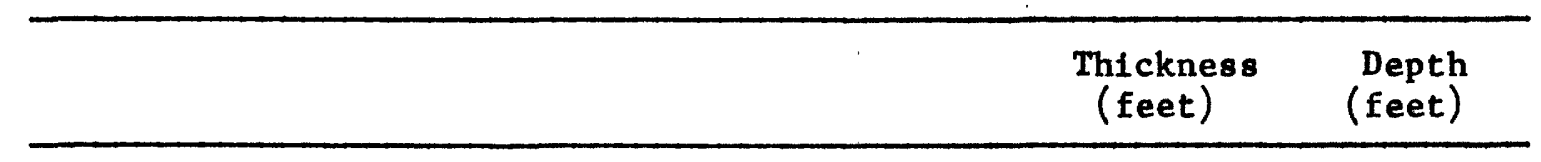

Bedrock

Tuff, pumiceous, friable; grayish-orange pink to pinkish gray; fine to medium grained; composed of fragments of pumice (white to grayish-orange pink, subangular to subround, 0.1 to $0.4 \mathrm{~mm}$, some calcareous) with numerous crystals of quartz and feldspar (euhedral to subhedral) and moderate amounts of biotite $(0.05$ to $0.1 \mathrm{~mm})$, amphibole, and magnetite; matrix, calcareous silt '(very pale orange)........... 110 470

Tuff, crystal, frlable; pale pink to pinkish gray, fine to medium grained; composed principally of crystals of quartz and feldspar (medium to fine sand, euhedral to subhedral), with a moderate amount of pumice fragments, biotite, magnetite, and amphibole; matrix, calcareous silt (very pale orange) .... 45

Sand, gravel, and silt; medium 1 ight gray to dark gray and pale pink; composed principally of dolomite (dark gray, medium to fine grained, subangular to angular), with 
Geologist's $10 \mathrm{~g}$ of Army well 1---Continued.

abundant fragments of crystal tuff (pale

plnk), minor amounts of quartzite, chert,

and argilite; calcium-carbonate coatings

sparse; matrix, calcareous silt (very pale

orange) ................. 95

610

Bedrock (Upper Cambrian (?))

Dolomite, dark gray; fine to medium grained ... 5

615

Similar, but with minor amount of calcite

(white, rhombohedra1) ....... 5 . 620 
Army we11 $6(68-69)$

Army we11 6 was intended for supplylng water to Camp Desert Rock, an Army post. It is in the same valley as the camp and 18 about $3 \mathrm{miles}$ southwest of Mercury. The Nevada State Coordinates of the site are N 680,800 and $E 690,500$ and the 1and-surface altitude of the well is 3,256 feet.

The well was drilled In 1951 by the McKinney Drilling Co., using the cable-tool method. It is 1,220 feet deep. The static water level in the wel1 in October 1951 reportedly was 975 feet below the land surface. The yield reported by the driller was only 3 gallons per minute. The well was abandoned because the water was of poor chemical quality.

\section{Drillers' $\log$ of Army wel1 6}

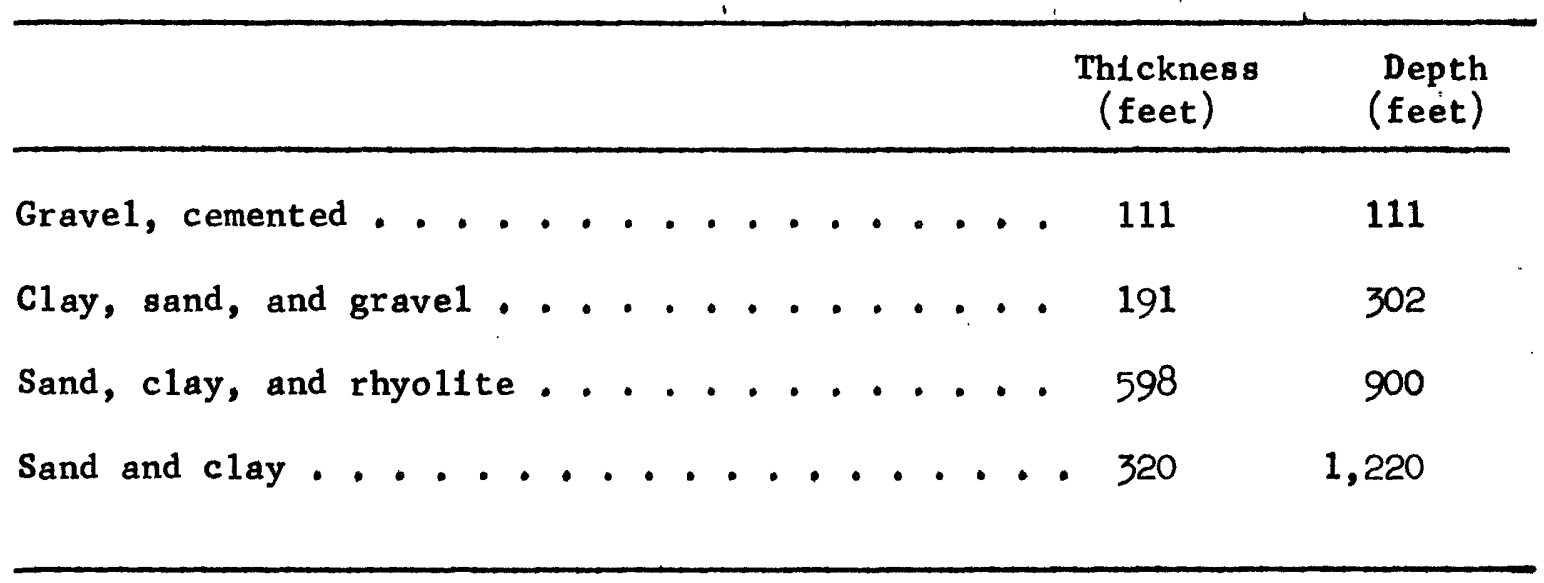




\section{We11 J-12 (73-58)}

We11 J-12 was drilled to supply water for operations of the Atomic Energy Commission in Jackass Flat. It is in Jackass Flat about 23 miles northwest of Mercury. The Nevada State Coordinates of the site are $N 733,509$ and $E 581,011$ and the 1and-surface altitude at the we11 is 3,128 feet.

The well was drilled in 1957 by the Perry Drilling Co., using the cable-tool method. It is 887 feet deep and is cased from the surface to the bottom with $123 / 4-$ inch casing, which in the interval from 793 to 868 feet is perforated.

The yield of the well during a 2-hour pumping test was reported to be 380 gallons per minute with only 4 feet of drawdown. The specific capacity was 95 gallons per minute per foot of drawdown. The well was put in service in June 1960 .

Details of construction and test pumping are given in reports prepared in 1959 and 1961 by the Burns and McDonnell Engineering Co., Kansas City, Mo.

The well penetrated alluvium from the surfice to 515 feet and tuff from 515 to 887 feet. An electrical $\log$ of the we11 is given in figure 2 .

The static water level in the well in Jdnuary 1960 was 741.4 feet below the land surface. 
Geologist's $\log$ of well J-12

By George E. Walker

Alluvium

Sand and gravel; very pale brown to yellowish brown; consisting of sedimentary tuff (pale red to very pale orange), silicified tuff (11ght brown to pale yellowlsh brown), and crystals of quartz and feldspar (clear to pink) with minor amounts of argi111te (11ght gray) welded tuff (brown and pale red), felsite (medium gray to light b'rownish gray), perlite (11ght gray), and glass (black) . . 515

Bedrock

Tuff, welded; pale red; consisting of flattened pumice 40 percent, crystals of quartz and feldspar 20 percent with minor amounts of black pumice, hornblende, and 11thics... . 35 550

Tuff, welded; grayish red; consisting of

flattened pumice 60 percent, and crystals of quartz and feldspar 10 percent with minor amounts of black pumice, and 11thics; some manganese-oxide coatings . . . . . . 10 
Geologist's 1 og of J-12--Continued

Tuff, pumiceous; grayish orange; consisting of

pumfce (pale orange pink) 65 percent, and crystals of quartz and feldspar 30 percent with minor amounts of black pumice and 1ithics . . 30

Tuff, vitrophyre; grayish red; consisting of pitchstone (grayish red), pumice with shards, and crystals of quartz and feldspar 30 percent with a minor amount of biotite and 1ithics.... 20

Tuff, vitrophyre; grayish black; consisting of obsidian (grayish black), pitchstone (pale orange, as streaks in obsidian), crystals of quartz and feldspar 30 percent, and biotite 5 percent . . 20 Tuff, welded (altered); pale red to pinkish gray; consisting of elongated pumice (some altered) 30 to 45 percent and crystals of quartz and feldspar 15 to 45 percent with minor amounts of biotite and lithics............. 100

Tuff, welded (altered); pinkish gray; consisting of flattened pumice (altered, some eutaxitic. structure) and crystals of quartz and feldspar with minor amounts of biotite and 1ithics . . 150 


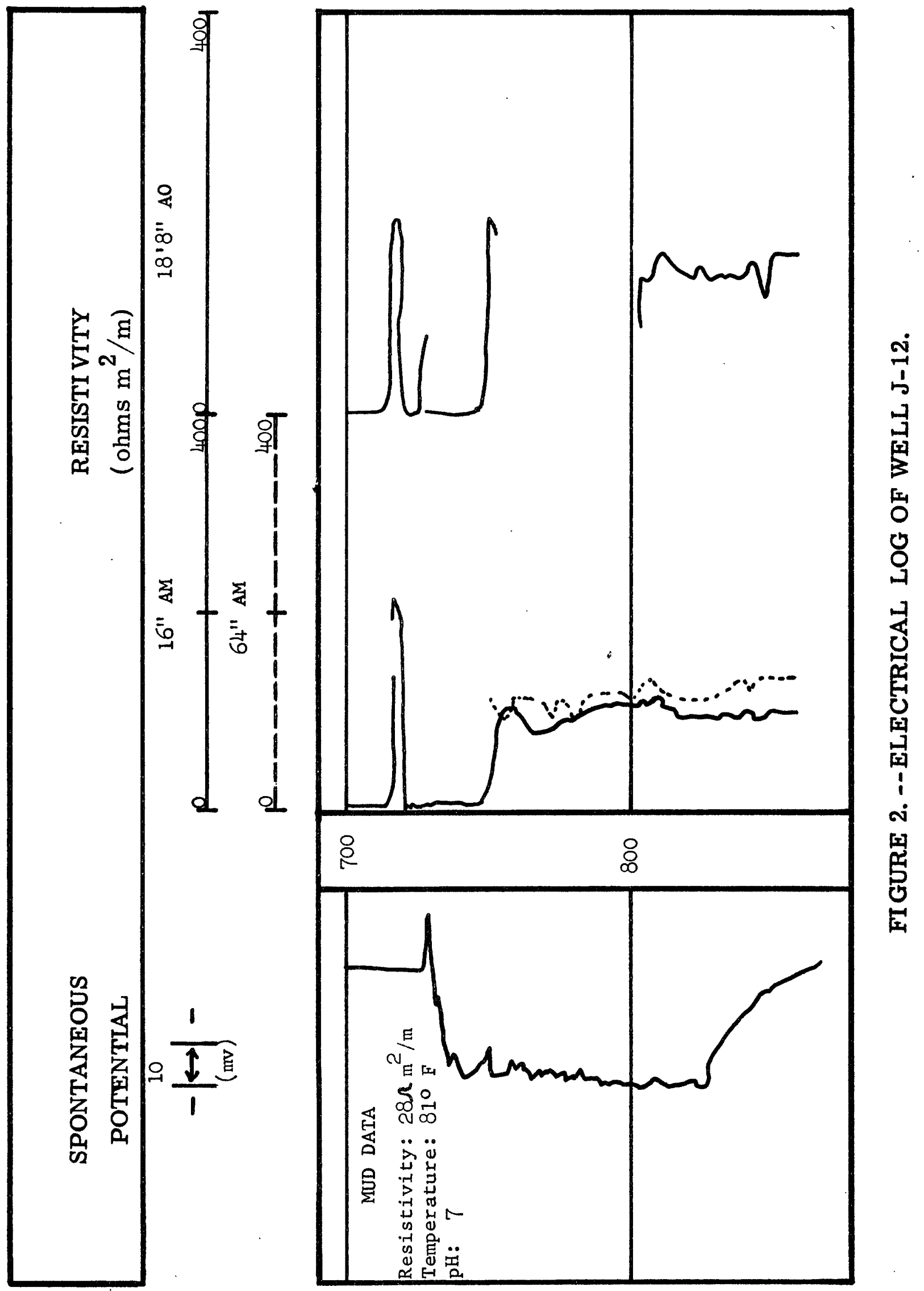




\section{We11 J-11 (73-61)}

We11 J-11 was intended for supplying water for operations of the Atomic Energy Commission in Jackass Flat. It is in Jackass Flat about 19 miles northwest of Mercury. The Nevada State Coordinates of the site are $\mathrm{N} 738,968$ and $\mathrm{E} 611,764$ and the land-surface altitude at the we11 is 3,445 feet.

The well was drilled in 1957 by the Perry Drilling Co., using the cable-tool method. It is 1,329 feet deep and is cased with 12 3/4-1nch casing from the surface to 1,327 feet. Casing in the intervals from 1,077 to 1,097 and 1,244 to 1,300 feet is perforated. The yleld during a 4-day pumping test was reported as 105 gallons per minute with a 40-foot drawdown. The specific yield was 2.6 gallons per minute per foot of drawdown.

The well penetrated alluvium from the surface to 1,025 feet, basa1t from 1,025 to 1,150 feet, and tuff from 1,150 to 1,329 feet. An electrical log of the well is given in figure 3.

The static water leve1. In the well in January 1958 was $1,037.5$ feet below the land surface. 
Geologist's $\log$ of we11 J-11

By George E. Walker, Isaac J. Winograd, and John E. Moore

\begin{tabular}{ll}
\hline $\begin{array}{c}\text { Thickness } \\
\text { (feet) }\end{array}$ & $\begin{array}{c}\text { Depth } \\
\text { (feet) }\end{array}$ \\
\hline
\end{tabular}

Alluvium

Sand and gravel; yellowish brown; consisting of sedimentary tuff (moderate reddish orange to pinkish gray, with calcareous cement) and quartz and feldspar crystals with minor amounts of argillite (brownish gray), chert (very pale orange), glass (black), gray perlite, biotite, and basalt....... 400400

Sand and gravel; moderate yellowish brown; conslsting of sedimentary tuff (very pale orange to yellowish gray) silicified tuff (moderate orange pink to grayish-orange pink), and quartz and feldspar crystals with minor amounts of arglilite (pale brown and orange pink), glass (pale olive), and basalt (brownish black) .........

Bedrock

Basa1t, aphanitic; medium gray to medium dark gray; containing irregular to tubular grains (white, calcareous, hardness $<5$, possible calcite amygdules) 15 to 30 percent and brown 1imonfte 2 to 4 percent ....... $45 \quad 1,070$ 
Geologist's 1 og of wel1 J-.L1--Continued

Basalt, aphanitic; medium gray to medium dark

gray; contains amygdules (some coated with

a soft white mineral), limonite, olivene

(translucent, greenish yellow), and crystals

of calcite and quartz......... . 80

Tuff, partially welded (porous); pinkish gray

and some pale red; quartz and feldspar

crystals 20 percent, and abundant glass shards

(11ght gray) with traces of lithics embedded

in a glassy matrix (a1tered) ...... 105

1,255

Tuff, crysta1-pumiceous, bedded; grayish orange

pink; composed of quartz and feldspar crystals,

lithics, and pumice with minor amounts of

blotite............... 25

1,280

Tuff, vitrophyre; grayish black and some gray-

ish red; consisting of obsidian (grayish

black), pitchstone (pale orange, as streaks

In obsidian), crystals of quartz and feldspar

30 percent, and biotite 5 percent.... 40

1,320

Tuff, welded; light red; composed of quartz

and feldspar crystals 15 percent, pumice,

and shards with minor amounts of biotite,

magnetite, and hornblende . . . . . 9

1,329 


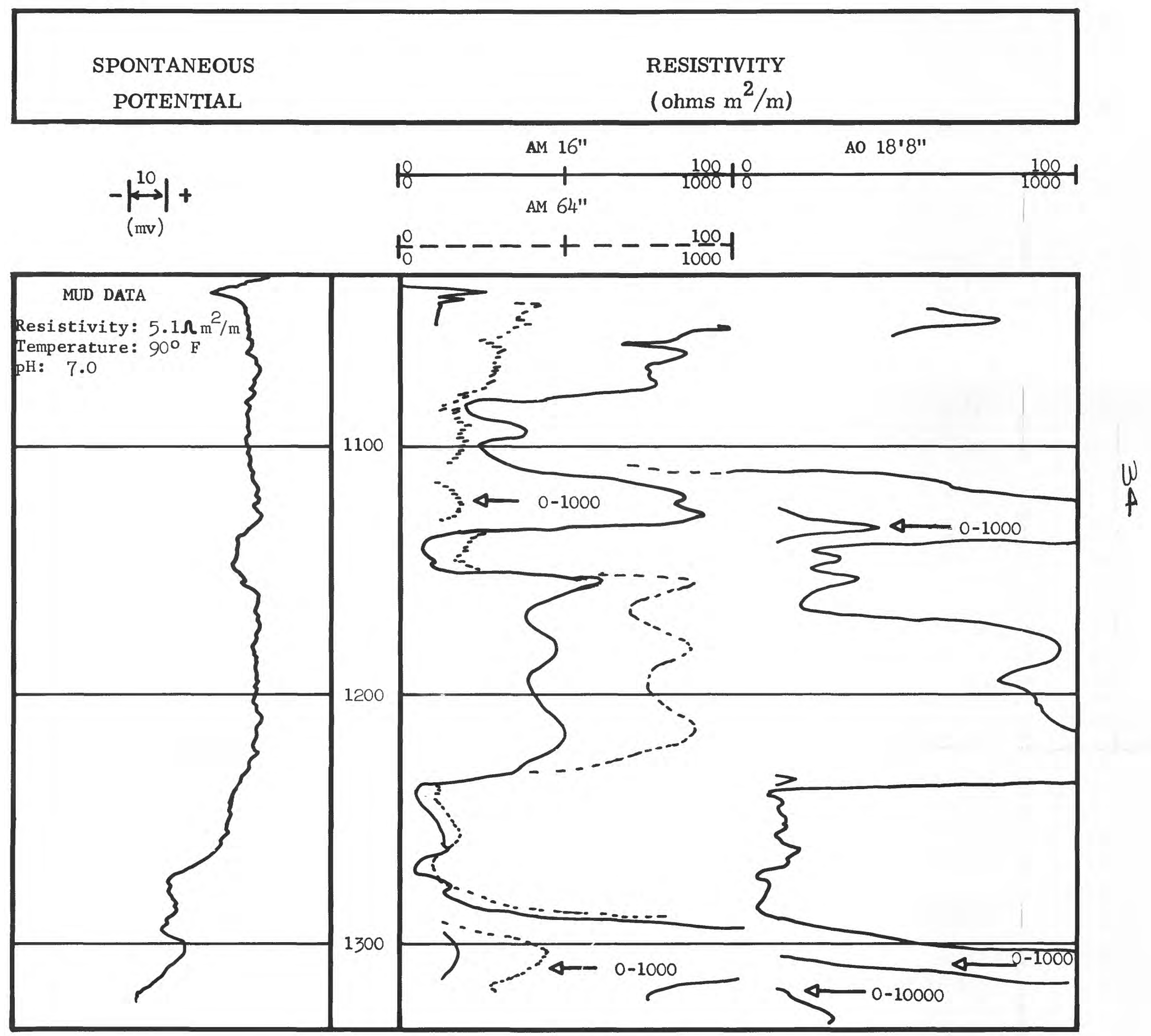

FIGURE 3.--ELECTRI CAL LOG OF WELL J-11. 

Test we11 5 (73-69)

Test wel1 5 was intended for supplying water for activities of the Atomic Energy Commission at the Nevada Test Site. It is in Frenchman Flat about 8 miles north of Mercury. The Nevada State Coordinates of the site are N 734,799 and E 690,124 , and the 1andsurface altitude at the well is 3,233 feet.

The well was drilled in 1950 by the McKinney Drilling Co., using the cable-tool method. It $1 \mathrm{~s}$ about 12 inches in diameter and $1 \mathrm{~s} 461$ feet deep, and is cased with 12-inch casing to a depth of only 8 feet. The well was abandoned as a dry hole after penetrating 134 feet of alluvium underlain by 327 feet of tuff.

A gamma-ray log run in test well 5 suggests that the alluviumbedrock contact is at 90 feet (Winograd, personal communication).

\begin{tabular}{ccc}
\hline $\begin{array}{c}\text { Th1ckness } \\
\text { (feet) }\end{array}$ & $\begin{array}{c}\text { Depth } \\
\text { (feet) }\end{array}$ \\
\hline
\end{tabular}

Alluvium

Gravel and sand; gray-brown ....... 34

Sand and gravel; gray-brown ....... 31

Sand and grave1; gray, cemented ...... 69

Bedrock

Tuff, soft; shades of red, brown, and gray . . 327 


\section{Wel1 $1(75-72)$}

We11 1 was intended for supplying water for activities of the Atomic Energy Commission at the Nevada Test Site. It is In Frenchman Flat about 12 miles northeast of Mercury. The Nevada State Coordinates of the site are N 751,509 and E 723,349 and the 1and-surface altitude at the well is 3,100 feet.

The well was drilled in 1950 by the McKinney Drilling Co., using the cable-tool method. It is 870 feet deep and is cased with 8 -1nch casing from the surface to 801 feet. Casing in the interval 602 to 801 feet is perforated. The yleld during a 30-minute pumping test was reported as 50 gallons per minute with a 38 -foot drawdown. The spectfic capacity was 1.3 gallons per minute per foot of drawdown. An attempt to increase the yield by dynamiting the well proved unsuccessful and the well was abandoned.

The static water level in the well in December 1950 was reported as 714 feet below the 1and surface.

$$
\text { Drillers' } \log \text { of well } 1
$$

Compiled by Reynolds Electrical and Engineering Co., Inc.

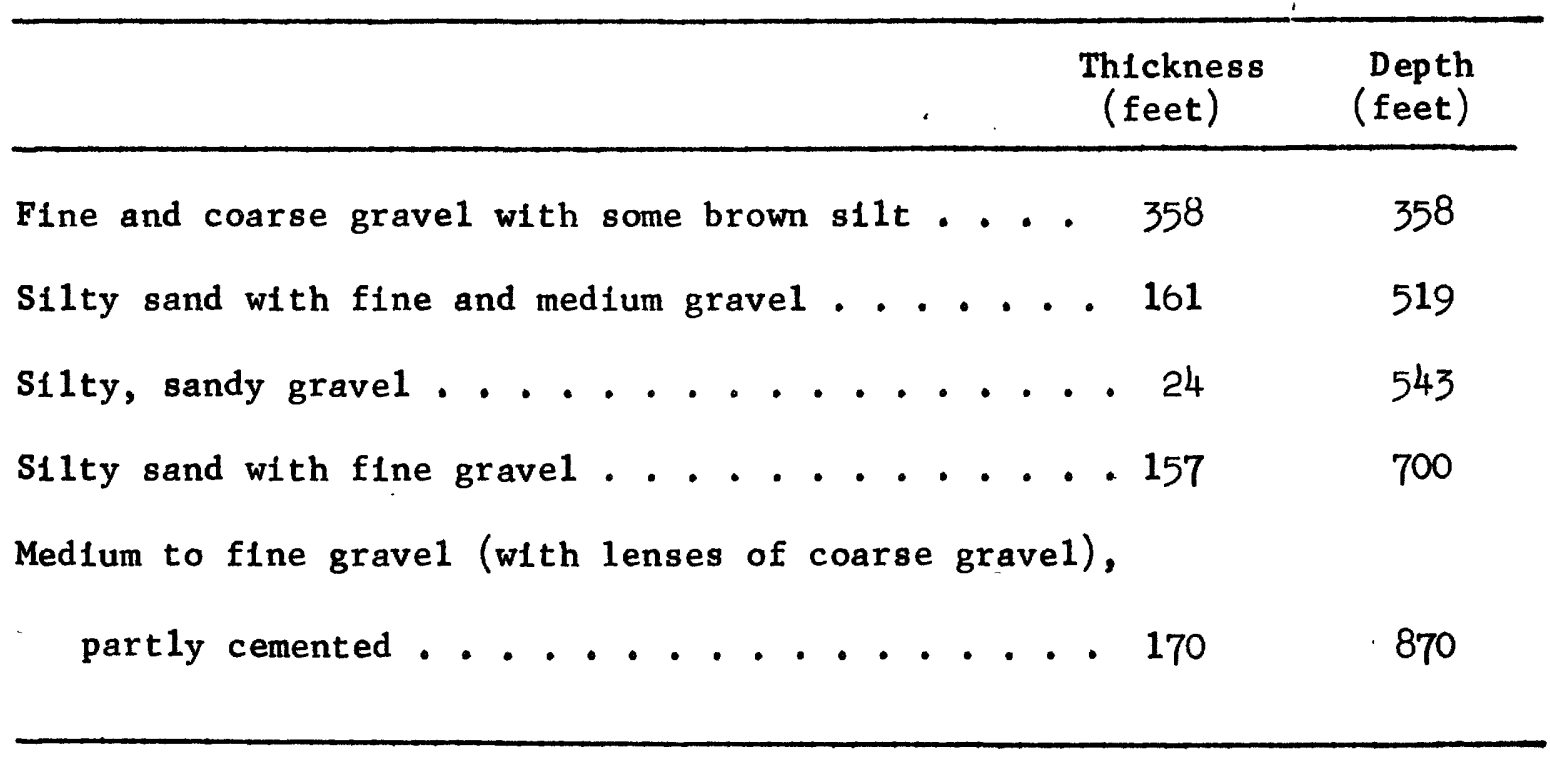


Test we11 $4(76-68)$

Test we11 4 was intended for supplying water for activities of the Atomic Energy Commission at the Nevada Test Site. It is in Frenchman Flat about 13 miles north of Mercury. The Nevada State Coordinates of the site are N 763,910 and E 689,551 and the 1andsurface altitude at the well is 3,405 feet.

The well was drilled in 1950 by the McKinney Drilling Co., using the cable-tool method. It is cased with 12-inch casing to a depth of only 8 feet. The well was abandoned as a dry hole at 172 feet.

Drillers' $\log$ of test well 4

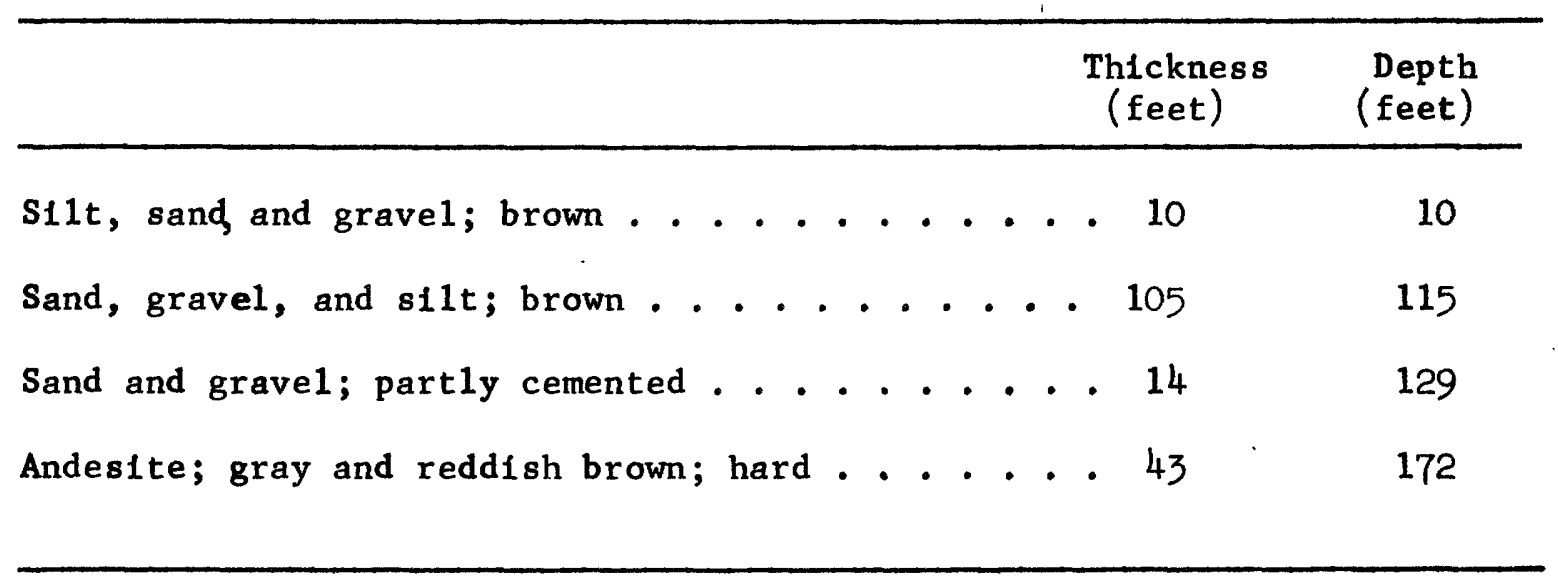


Gravity h1gh test hole $2(83-67)$

Gravity high test hole 2 was drilled in 1959 to determine the depth to bedrock where a gravity survey had indicated the bedrock to be close to the surface. It was not intended to develop a water supply. The site is in the northern part of Yucca Flat about 2.m1les southwest of the B-J junction of the Mercury highway. The Nevada State Coordinates of the site are $\mathrm{N} 834,800$ and $\mathrm{E} 671,650$ and the land-surface altitude at the hole $1 \mathrm{~s}$ about 4,120 feet.

The hole was drilled in 1959 by the Geological Survey, using the rotary-hydraulic method, to a depth of only 92 feet. It penetrated alluvium from the surface to 72 feet, and 11mestone and shale from 72 feet to the bottom. The limestone has been identified tentatively as belonging to the lower part of the Pogonip Group. On1y rotary cuttings were avallable for the Interval from 0 to 72 feet and these were not described in detall because the objective was the underlying bedrock. The 1og, therefore, consists chiefly of a description of the 20 feet of core taken from the bedrock. 
Geologist's $10 \mathrm{~g}$ of Gravity high test hole?

By F. M. Byers, Jr.

Thickness
(feet) $\quad \begin{gathered}\text { Depth } \\ \text { (feet) }\end{gathered}$

Alluvium

Alluvial f111, possibly with some weathered

bedrock . . . . . . . . . . . . 72

Bedrock (Pogonfp Group(?))

Limestone, medlum bluish-gray and slightly

darker, (mottled and streaked with pale

yellowlsh brown); few exposed shaly partings

parallel to and within $1 / 2$ inch of bedding

surfaces (yellowish gray to pale olive);

bedding surfaces make angle of $15^{\circ}$ to $20^{\circ}$

with horfzontal; some surfaces wavy,

suggestive of ripple marks; Indistinct

tribolite and graptolite (?) fragments ... 15 (?)

$87(?)$

LImestone, medium gray to pale yellowish-

brown; flnely granular; many randomly

orlented whtte calcite-f1lled fractures,

Increasing toward base of unit. . . . . 4 (?)

$91(?)$

Shale or siltstone, calcareous; pale greentsh

yellow with sparse dark yellowlsh orange;

stain on broken (fracture) surface; shaly

parting poor................ 1 (?)

$92(?)$ 
Gravity high test hole $1(87-66)$

Gravity high test hole 1 was drilled in 1959 to determine the depth to bedrock where a gravity survey had indicated the bedrock to be close to the surface. It was not intended to develop a water supply. The site $1 \mathrm{~s}$ in the northern part of Yucca Flat about $6 \mathrm{miles}$ northwest of the B-J junction of the Mercury highway. The Nevada State Coordinates of the site are $N 873,000$ and $E 662,700$ and the land surface altitude at the hole is about 4,440 feet.

The hole was drilled in 1959 by the Geological Survey, using the rotary-hydraulic method, to a depth of 145 feet. It penetrated alluvium from the surface to 130 feet and dolomite from 130 to 145 feet. On1y rotary cuttings were available for the interval from 0 to 130 feet, and these were not described in detall because the objective in drilling the hole was to locate the underlying bedrock. The $10 \mathrm{~g}$, therefore, consists malnly of description of the 15 feet of bedrock core. 
Geologist's log of Gravity high test hole 1

By F. M. Byers, Jr.

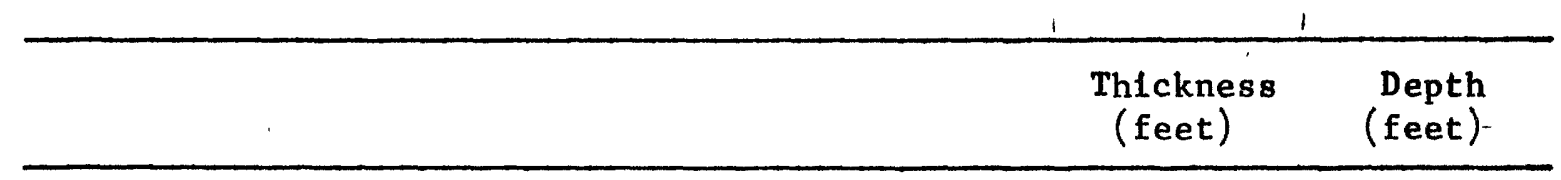

Alluvium

Alluvial flil :............. 130

Bedrock (Bonanza King Formation)

Dolomite-pebble conglomerate; calcareous, sandy;

pebbles of medium gray to medium-1ight gray

dolomfte; matrlx, yellowlsh gray, calcareous

and sandy .............. 1

131

Dolomite; medlum gray to medium-dark gray; fractured;

cryptocrystalline to finely crystalline .... 1

Dolomite; 11ght gray to medium-1ight gray; in

fine laminations 0.5 to $2.0 \mathrm{~mm}$ (cryptocrystalline,

dip $25^{\circ}$ to $30^{\circ}$ ) high-angle fractures dip $60^{\circ}$ to

$70^{\circ}$ at high angle to lamfnae; few vague and

indistinct low-angle fractures; fractures

filled with finely crystalline calcite .... 3

Dolomite; medium-1ight gray, in fine laminations,

slightly calcareous, cryptocrystalline;

fractures as above; laminae dip $35^{\circ} \ldots . . .3$

Dolomitic 11mestone; medium-1ight gray, medium

gray, and medfum-dark gray; 1aminations 0.5 to

$5 \mathrm{~mm}$ (medium to medium-dark gray laminae predoml-

nate and are less dolomitic, darker gray laminae 
Geologist's $\log$ of Gravity high test hole 1.--Continued

ontt strong fetid odor when struck with

hammer) subparallel high-angle fractures

$60^{\circ}$ to $70^{\circ}$; lamlnae somewhat Irregular;

$\operatorname{dip} 27^{\circ}$ to $35^{\circ}$................ 4

Dolomfte, 11ght gray to medlum 11ght gray; few

laminae yellowlsh gray; cryptocrystal11ne . . 0.5

Dolomitic 11mestone; medlum gray, highly frac-

tured; no laminae vistble......... 0.5

143

Dolomite; 11ght olive gray, 11ght yellowish gray

near fractures; indistinct lamfnae (highly

fractured, cryptocrysta11ine); fractures

fllled with finely crystalline dolomite . . . 1

Dolomitic limestone; medlum-light gray to

medlum gray, some laminae light ollve

gray; cryptocrystalline; laminae dip

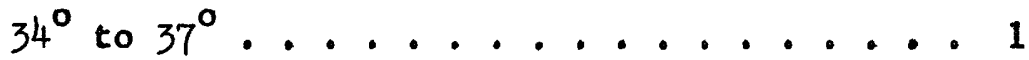




\section{Effinger we11 4 (88-64-a)}

Effinger wel1 4 was intended for supplying water for activities of the Atomic Energy Commission at the Nevada Test Site and for determining the depth to bedrock. It is in the northern part of Yucca Flat about $11 \mathrm{mlles}$ northwest of the B-J junction of the Mercury highway. The Nevada State Coordinates of the site are $N 886,025$ and $\mathbf{E} 643,216$ and the land-surface altitude at the well 185,603 feet.

The well was drilled in 1959 by the Effinger Drilling Co., using the cable-tool method. It 18 cased with 5 5/8-inch casing from the surface to 70 feet. The well was abandoned as a dry hole at 76 feet.

The well penetrated alluvium from the surface to 65 feet and tuff from 65 to 76 feet. 


\section{Geologist's log of Effinger well 4 \\ By Charles E. Price}

\section{Alluvium}

Sand, gravel, and silt; pale grayish orange;

tuff (yellow and some red) 70 percent, colorless crystals 10 percent, quartzite (11ght colors) 10 percent and dolomite (medlum to dark gray) 10 percent..... 35

Sand, gravel, and silt; pale graylsh orange;

tuff (yellow and some red) 85 percent, crystals (colorless, transparent) 5 percent, quartzite (11ght colors) 5 percent and dolomite (medium to dark gray) 5 percent. . 30

Bedrock

Tuff; medlum yellowish orange; tuff (slightly

calcareous) 95 percent and crystals

(colorless, transparent) 5 percent ..... 11 


\section{Effinger we11 2 (88-64-b)}

Effinger we11 2 was intended for supplying water for actlvitles of the Atomic Energy Commission at the Nevada Test Site and for determining the depth to bedrock. It is in the northern part of Yucca Flat about $11 \mathrm{mlles}$ northwest of the $\mathrm{B}-\mathrm{J}$ junction of the Mercury highway. The Nevada State Coordinates of the site are N 886,283 and E 643,089 and the land-surface altitude at the well is 5,598 feet.

The well was drilled in 1959 by the Effinger Driling Co., using the cable-tool method. It is cased with 6-1nch casing from the surface to 10 feet. The well was abandoned as a dry hole at 80 feet.

The hole penetrated alluvium from the surface to $40 \mathrm{feet}$, and argil11te and quartzite from 40 to 80 feet. 
Geologist's log of Effinger we11 2

By Charles E. Price

\section{Alluvium}

Sand, silt, and gravel; pale yellowish orange grading to 11 ght yellowish gray at bottom; consisting of tuff (red and yellow hues, calcium-carbonate cement) 70 percent, crystals (transparent, colorless) 5 percent, and dolomite (medium to dark gray) 25

percent . . . . . . . . . . 40 40

Bedrock (Eleana Formation)

Argillite and quartzite; yellowish gray; consisting of argilite and quartzite (fine grained, some white quartz fracture f1111ngs) 90 percent; iron oxide stains on fracture surfaces.......... 40 
Effinger wel1 $1(88-65)$

Effinger wel1 1 was intended for supplying water for activites at the Atomic Energy Commission at the Nevada Test Site and for determining the depth to bedrock. It is in the northern part of Yucca Flat about 10 miles northwest of the B-J junction of the Mercury highway. The Nevada State Coordinates of the site are N 888,562 and E 650,404 and the land-surface altitude at the well is 5,152 feet.

The well was drilled in 1959 by the Effinger Drilling Co., using the cable-tool method. It 1s cased with 6-1nch casing from the surface to 10 feet. The we11 was abandoned as a dry hole at 180 feet. The hole penetrated alluvium from the surface to 165 feet and quartzite from 165 to 180 feet. 
Geologist's $\log$ of Effinger well 1

By Charles E. Price

\section{Alluvium}

Sand, gravel, and silt; pale gray to pale orange; consisting of tuff (red and greenish yellow) 40 percent, quarzite and argillite 35 percent, dolomite (dark gray, fine grained) 20 percent and crystals (colorless, transparent, less than $2 \mathrm{~mm}) 5$ percent; coatings of calcite and dolomite on some fractures. . 135

Sand, gravel, and silt; very pale orange grading to dark orange pink at the bottom; consisting of quartzite and argil11te 50 percent, tuff (red, white and green) 40 percent, crystals (colorless, transparent) 5 percent and dolomite (dark gray) 5 percent ......... 30

Bedrock (E1eana Formation)

Quartzite; moderate orange pink to 11ght brown; quartzite (white and red) 90 percent; dolomite (dark gray to black) 5 percent . . . 15 


\section{Effinger well $3(89-65-a)$}

Effinger we11 3 was intended for supplying water for activities of the Atomic Energy Commission at the Nevada Test Site and for determining. the depth to bedrock. It $1 \mathrm{~s}$ in the northern part of Yucca Flat about 11 miles northwest of the $B-J$ function of the Mercury highway. The Nevada State Coordinates of the site are N 891,026 and E 652,714 and the land-surface altitude at the we11 is 5,032 feet.

The wel1 was drilled in 1959 by the Effinger Drilling Co., using the cable-tool method. It is cased with 5 5/8-inch casing from the surface to 200 feet. The well was abandoned as a dry hole at 202 feet.

The hole penetrated alluvium from the surface to 190 feet and argil11te from 190 to 202 feet.

$$
\begin{gathered}
\text { Geologist's log of Effinger well } 3 \\
\text { By Charles E. Price }
\end{gathered}
$$

Alluvium

Sand, gravel, and silt; pale grayish orange to very pale orange; consisting of tuff (yellow and red hues) 75 percent, crystals (colorless, transparent) 10 percent, argil11te and quartzite 10 percent and dolomite (gray) 5 percent . . . 190

Bedrock (Eleana Formation)

Argillite; dark reddish brown . . . . . . . 12 
Watertown wel1 $2(90-75)$

Watertown we11 2 was intended for supplying water for activities of the Atomic Energy Commission. It is in the central part of Emigrant Va1ley, and the Nevada State Coordinates are N 909,062 and E 752,226. The land-surface altitude at the well is 4,437 feet.

The well was drilled in 1955 by the Allen and Falling Co., using both cable-tool and rotary equipment. It is 1,091 feet deep and 1s cased with 12-1nch casing from the surface to 346 feet, 10-inch casing to 804 feet, and 8 -inch casing to 1,091 feet. The yleld during a 30-minute pumping test was reported as 15 gallons per minute with a 26-foot drawdown. The specific capacity was 0.58 gallon per minute per foot of drawdown.

The well penetrated alluvium from the surface to 370 feet and tuff from 370 to 982 feet. The static water level in the well in October 1955 was reportedly at 896 feet below the land surface.

The $\log$ was prepared from samples collected by the drilier. Only three samples were collected in the depth interval from 0 to 600 feet and these are inadequate for describing so large an interval. An electrical $\log$ of the well is given in figure 4. 
Geologist's $\log$ of Watertown we11 2

Summary of fleld $\log$ by Omar $J$. Loeltz and Glen T. Malmberg

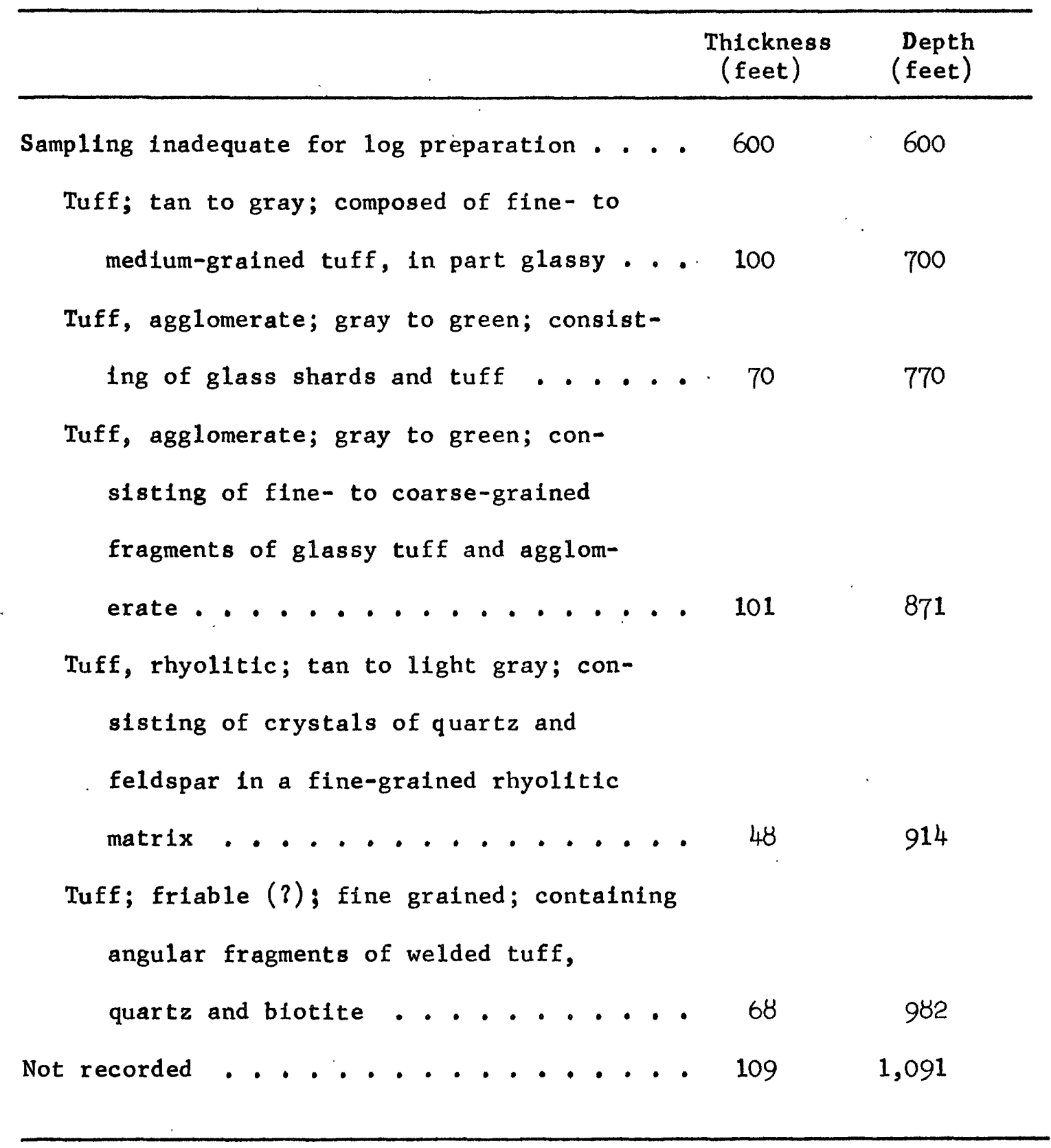




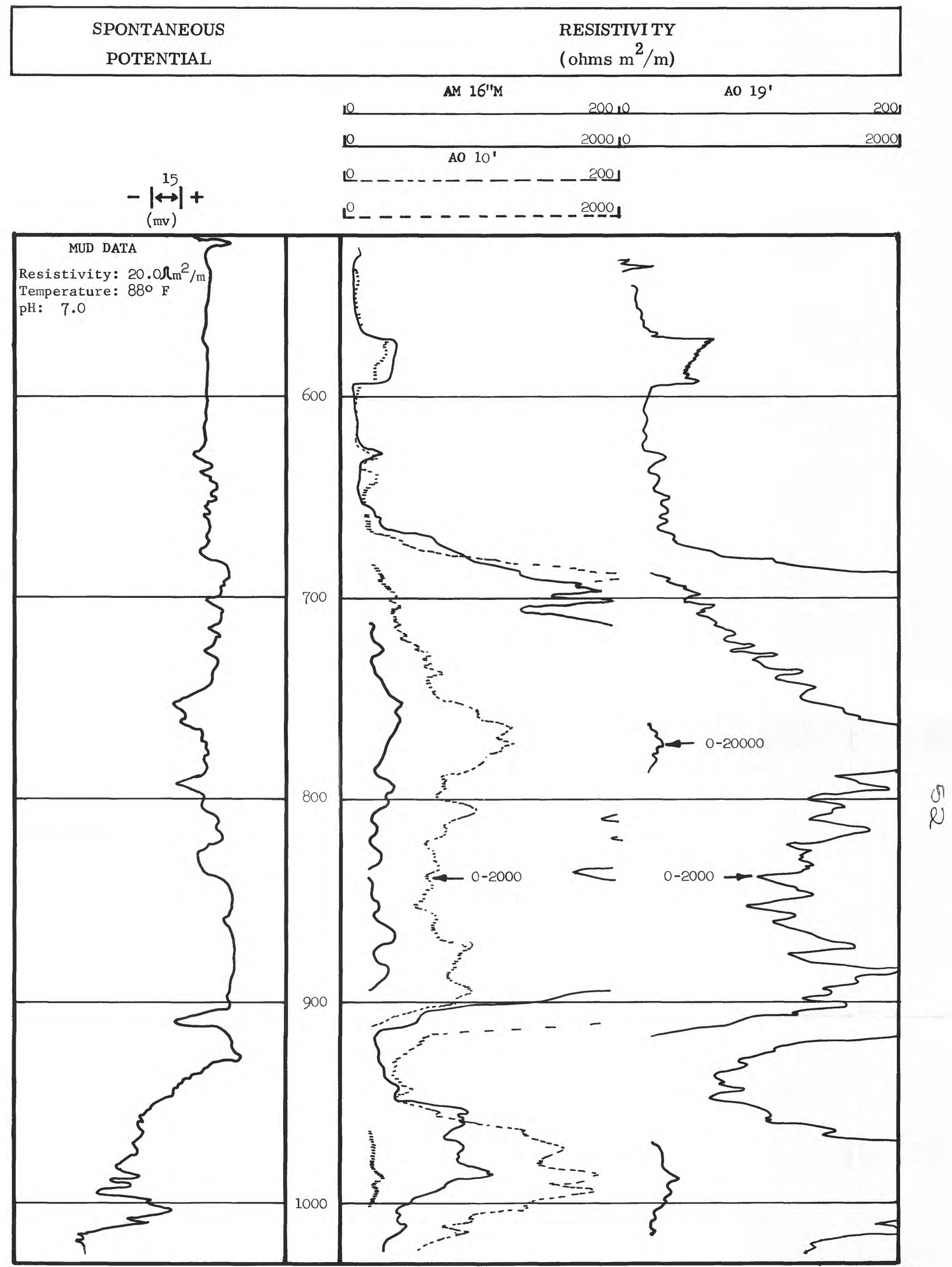

FIGURE 4. --ELECTRICAL LOG OF WATERTOWN WELL 2. 



\section{REFERENCES CITED}

Bunker, C. M., 1961, Gamma-radioactivity investigations at the Nevada Test Site, Nye and Lincoln Counties, Nevada: U. S. Geo1. Survey TEI-778, 95 p., 52 figs., 2 tables.

Barnes, Harley, Houser, F. N., and Poo1, F. G., 1961, Geologic map of the Oak Spring Quadrangle, Nye County, Nevada: U. S. Geol. Survey open file report.

Dickey, D. D., and McKeown, F. A., 1959, Geology of Dolomite Hil1, Nevada Test Site, Nye County, Nevada: U. S. Geo1. Survey TEI-755, 64 p., 3 figs., 5 tables.

Goddard, E. N., Trask, P. D., DeFord, R. K., Rove, O. N., Singweld, J. T., and Overbeck, R. M., 1951, Rock color chart: Geol. Soc. America (2nd Printing).

Hansen, W. R., and Lemke, R. W., 1957, Geology of the USGS and Rainier tunnel areas, Nevada Test Site: U. S. Geol. Survey TEI-716, 111 p., 6 figs., 7 tables.

Houser, F. N., and Pool, F. G., 1959, "Granite" exp1oration hole, Area 15, Nevada Test Site, Nye County, Nevada--Interim report, Part A, Structural, petrographic, and chemical data: U. S. Geol. Survey TEM-836, 58 p., 5 figs., 11 tables. 1959, Lithologic $\log$ and drilling information for the marble exploration hole 3, U15 area, Nevada Test Site, Nevada: U. S. Geol. Survey TEM-1031, 22 p., 2 figs., 4 tables.

Hood, J. W., 1961, Water wells in Frenchman and Yucca Valleys, Nevada Test Site, Nye County, Nevada: U. S. Geol. Survey TEI-788, 59 p., 13 figs., 6 tables. 
Johnson, M. S., and Hibbard, D. E., 1957, Geology of the Atomic Energy Commission Nevada Proving Ground Area, Nevada: U. S. Geo1. Survey Bul1. 1021-K, p. 333-384, 2 p1., 1 f1g.

Mckeown, F. A., and Wilmarth, V. R., 1959, Geology of the marble exploration hole 4, Nevada Test Site, Nye County, Nevada: U. S. Geol. Survey TEM-1036, 26 p., 4 figs., 10 tables.

Moore, J. E., 1961, Wel1s, springs, and tèst holes in the Nevada Test Site and surrounding area: U. S. Geol. Survey TEI-781, 22 p., 1 fig., 5 tables.

Schoff, S. L., and Winograd, I. J., 1961, Hydrologic significance of six core holes in carbonate rocks of the Nevada Test Site: U. S. Geol. Survey TEI-787, 97 p., 4 figs., 10 tables.

Wilmarth, V. R., Healey, D. L., Clebsch, Alfred, Jr., Winograd, I. J., Zietz, Isidore, and O1iver, H. W., 1959, A summary interpretation of geologic, hydrologic, and geophysical data for Yucca Valley, Nevada Test Site, Nye County, Nevada: U. S. Geol. Survey TEI-358, 55 p., 5 figs., 6 tables. 
